\title{
Cancer stem cells and oral cancer: insights into molecular mechanisms and therapeutic approaches
}

\author{
Ghazaleh Baniebrahimi ${ }^{1}$, Fatemeh Mir $^{2}$ and Razieh Khanmohammadi ${ }^{*}$
}

\begin{abstract}
Cancer stem cells (CSCS) have been identified as a little population of cancer cells, which have features as the same as the cells normal stem cells. There is enough knowledge of the CSCs responsibility for metastasis, medicine resistance, and cancer outbreak. Therefore, CSCs control possibly provides an efficient treatment intervention inhibiting tumor growth and invasion. In spite of the significance of targeting CSCs in treating cancer, few study comprehensively explored the nature of oral CSCs. It has been showed that oral CSCs are able to contribute to oral cancer progression though activation/inhibition a sequences of cellular and molecular pathways (microRNA network, histone modifications and calcium regulation). Hence, more understanding about the properties of oral cancers and their behaviors will help us to develop new therapeutic platforms. Head and neck CSCs remain a viable and intriguing option for targeted therapy. Multiple investigations suggested the major contribution of the CSCs to the metastasis, tumorigenesis, and resistance to the new therapeutic regimes. Therefore, experts in the field are examining the encouraging targeted therapeutic choices. In spite of the advancements, there are not enough information in this area and thus a magic bullet for targeting and eliminating the CSCs deviated us. Hence, additional investigations on the combined therapies against the head and neck CSCs could offer considerable achievements. The present research is a review of the recent information on oral CSCs, and focused on current advancements in new signaling pathways contributed to their stemness regulation. Moreover, we highlighted various therapeutic approaches against oral CSCs.
\end{abstract}

Keywords: Oral cancer stem cells, Pathogenesis, Molecular pathways

\section{Introduction}

It is widely accepted that the head and neck cancers involve above 650,000 people and 330,000 mortality each year throughout the world [1]. For example, the head and neck cancers involve 3\% of the malignancy with 53,000 Americans, whose head and neck cancers developed every year and 10,800 who died due to this diseases in the United States [2]. Moreover, about 250,000 people (estimation showed $4 \%$ of the cancer occurrence) and 63,500 deaths have been reported in Europe in 2012 [3].

*Correspondence: razie.khanmohammadi@yahoo.com

${ }^{1}$ Department of Pediatric Dentistry, School of Dentistry, Tehran University of Medical Sciences, Tehran, Iran

Full list of author information is available at the end of the article
In addition, the commonest malignancy has been considered to be the squamous cell carcinoma (SCC) and the respective variants.

According to a study in the field, diets, oral hygiene, carcinogen exposure, family history, infectious agents, as well as the pre-existing medical conditions contributed separately or jointly to the HNSCC progression. Among the mentioned cases, tobacco smoking has been completely shown as one of the predominant risk factors for HNSCC and such as risk had a correlation to duration and intensity of smoking. It has been also found that quitting the smoking reduced but did not overcome the risks of the cancer expansion [4]. In addition, environmental exposure to the smoking of tobacco; that is, passive smoking apparently enhanced the risks of the 
HNSCC progression even for people who had at all experienced active smoking [4].

Studies also showed the use of heavy alcohol as one of the independent risk factors for HN-SCC, especially for hypopharynx cancer [5]. Even though exposure to tobacco and use of alcohol involved in most HNSCCs occurring in larynx, hypopharynx, and oral cavity, their contribution to the oropharynx tumorigenesis was minor. On the other hand, authors approved the oncogenic HPV, specifically Type 16 , as one of the causes in about $70 \%$ of the oropharyngeal cancers [6]. However, as the cigarette smoking declined in several regions worldwide, the HPV16 infection would be the greatest risk factor, shifted of HNSCC demographic towards younger patients with no experience of smoking or drinking. Actually, conventional risk factors like exposure to alcohol and tobacco, had no contribution to the HPV-mediated carcinogenesis of oropharynx [6]. Put differently, HPV-related HNSCC showed a close correlation to the oral HPV infection and specific sexual positions, which facilitated iterative viral exposure, including the early age of the sexual debuts, the increased numbers of the life-time oral sexual and vaginal partners, recurrent oral-anal and oral-genital contacts, as well as rare application of the barrier in the course of sexual activities [7]. Even though researchers have enough data of the risk factors for the viral transmission, they emphasize the ones related to the consequent HPV-induced tumorigenesis. Moreover, authors suggested specific situations and behaviors, which altered the anti-tumor immunity, as the potent parameters affecting the viral persistence and tumor expansion. Long examined carefully as one of the potent sources of the DNA-damaging carcinogens. It has been shown that smoking marijuana could have higher relationship with progressing the HPV-positive HNSCCs for its immunoregulatroy impacts. Therefore, cannabinoids bound to CB2 receptor expressed on the B-cells, T-cells, NK-cells, dendritic cells, and macrophages in the humans' tonsillar tissues. Hence, binding had been capable of suppressing the immune response, diminishing the host response to the viral pathogen, and attenuating antitumor activities [8-10]. Consequently, using the marijuana might influence each stage of the HPV-induced tumorigenesis from the time of infection initiation to the viral persistence, tumor induction, metastasis, and growth [11].

In terms of clinical examinations, organized lesions, including leukoplakia, which are histologically categorized as the non-dysplastic or dysplastic leukoplakia, frequently come before head and neck cancer. Nonetheless, researchers characterized dysplastic leukoplakia as one of the oral pre-malignant lesions related to a possibly development to cancers. Nonetheless, the researchers did not regard dysplastic leukoplakia as one of the precise predictors of the cancer risks $[12,13]$. Several therapeutic approaches i.e., cell therapy, gene therapy, nanotechnology-based therapies, utilization of natural compounds are used in the treatment of different cancers such as oral cancers [14-22]. In general, it is possible to manage initial-phase tumors via radiotherapy and surgery; however, successful therapy has an inverse proportionate to the extent of disease while treating. If chemotherapy and radiation treatment are combined, even though they affect the treatment of $97 \%$ of the initial-phase tumors, they just $33 \%$ affect the treatment of the advanced tumors [23].

Current research discovered and verified the pathophysiologic contribution of CSCs that are also defined as tumor-initiating cells in the lengthy maintenance of cancers [24, 25]. It is widely accepted that CSCs are little sub-populations of tumor cells sharing several molecular similarities to the embryonic and normal adult stem cells. Some researchers separated CSCs from a variety of main tumors and created cancer cell lines such as OSCC [26-32]. These CSCs contribute crucially to the metastasis, tumorigenicity, and recurrence. For this reason, they are regarded as the origin of the cancer. Hence, it is necessary to increase knowledge of the molecular features and signaling paths specific to the oral CSCs in order to develop new targeted and efficient treatments for head and neck cancer.

\section{Oral cancer stem cells isolation}

The first reports of the presence of a CSC population has been related to the leukemic cells [33]. Positive and negative staining of the leukemic CSC population has been done with CD34 and CD38 (CD34 $\left.{ }^{+} / \mathrm{CD} 38\right)$, respectively. They were able to develop leukemia while inoculating onto immunocom-promised mice. Afterwards, researchers have widely investigated the CSC populations, and substantially determined them in different solid tumors like the prostate, neck, pancreas, colon, head, brain, and breast [34-37]. The existence of sub-populations of oral CSCs has been primarily proposed by the study, which showed just a sub-population of OSCC cells is able to create a developing tumor mass [38]. Chiou et al. showed that a sub-population of OSCC cells extracted from the cultivated OSCC cell lines have features of the two stem cells and invasive malignant tumors such as self-renovation, tumorigenic potentials, migratory abilities, and radio-resistance [26]. Multiple researchers published information of the successful separation of oral CSC populations via different markers [26-32, 39, 40]. Generally, cancer stem cells in OSCC are possibly separated via the cell-surface markers or the respective specific practical features [41-43]. Yet, any specific marker and CSC feature cannot particularly isolate oral CSCs populations 
from OSCC cells, which demonstrate that CSC populations are heterogeneous $[44,45]$. Hence, it would be crucial to identify further oral CSC markers and the respective cellular features.

Several research found differential expression of CD44 on cancer stem cells against non-cancer stem cells in different solid tumors $[46,47]$. These $\mathrm{CD} 44^{+}$CSC populations have been substantially isolated from the head and neck cancers via flow cytometry sorting through CD44 antibody [34, 39, 40]. CD44 that is a multi-functional trans-membrane glycoprotein attaches to hyaluronan. It acts as an essential surface molecule, which is capable of interacting with different intrinsic and extrinsic signals for regulating several gene expressions. It is widely accepted that $\mathrm{CD} 44^{+}$cells may be fractionated from heterogeneous single-cell-prepared cancer cells via CD44 specific antibody labeling accompanied by the flow cytometry arrangement [48]. Such $\mathrm{CD} 44^{+}$cells have definite features of the stem cells such as self-renovation capacities, great tumorigenic potentials, metastasis, and resistance to medicine $[46,47]$. If the CD44 is inhibited under experimental conditions, CD $44^{+}$CSCs decline their stemness features, which shows expressing CD44 is crucial to preserve the CSC phenotype [46].

Researchers applied ALDH1 activity as a cancer stem cell marker for a variety of cancers such as OSCC [4951]. It is a cytosolic iso-enzyme that has control over the oxidation of intra-cellular aldehydes. It involves in the retinol oxidation to retinoic acid in the initial stem cell differentiation [52]. One of the subpopulations of the cancer cells with improved CSC activities indicates great activities of ALDH1 (ALDH1 $1^{\mathrm{HIGH}}$ or $\mathrm{ALDH}^{+}$) in comparison with the non-CSC population, indicating that $\mathrm{ALDH}^{+}$cells are possibly an origin of CSCs $[27,53,54]$. In addition, $\mathrm{ALDH} 1{ }^{\mathrm{HIGH}}$ cancer cells have higher CSC traits than the ALDH1 $1^{\text {low }}$ cells $[34,51,55]$. Targeting ALDH1 largely inhibits several CSC features in human cancer cells [56]. Nonetheless, there is still controversy of the issue if CD44 or ALDH1 itself may be described as one of the unique molecules for identifying cancer stem cells or not. Therefore, researchers usually employed combining ALDH1 and CD44 as one of the markers to separate cancer stem cells in the head and neck cancer cells [34]. In fact, $\mathrm{ALDH} 11^{\mathrm{HIGH}} / \mathrm{CD} 44^{+}$cancer cells have higher CSC features than the $\mathrm{ALDH} 1^{\text {low }} / \mathrm{CD} 44^{-}$cancer cells $[57,58]$, illustrating that combining CSC markers can ameliorate CSC isolation specificity.

CSCs are able to improve themselves in the nonadherent tumor spheres cultivated in ultra-low binding plates for supporting un-differentiated development of self-renovating stem cells [59]. Researchers found that the sphere medium would be in a serum-free situation complemented with sufficient mitogens, including fundamental fibroblast development agent and epidermal growth factor (EGF) [60-62]. Plentifulness and growth kinetics of the tumor spheres represent self-renovation capacities in a certain cultivation of heterogeneous cancer cells, which indicates the contents of cancer stem cells. Therefore, researchers proposed that the tumor sphere-forming assay would be one of the popular techniques employed for isolating cancer stem cells from heterogeneous cancer cell populations via certain practical property of cancer stem cells. It should be noted that the tumor sphereforming cells detected in several major tumors and cultured cancer cell lines showed higher features of cancer stem cells in comparison with the features of the relative adherent mono-layer cells, which have been regarded as non-CSCs [63]. It has been known that the tumor sphere-forming cells enjoy the increased tumorigenicity, metastatic potentials, and medicine resistance as well as influential expression of stemness agents, which indicates their crucial contribution to pathogenezing and progressing cancers [64-69]. As such, tumor spheres extracted from OSCC cells show higher stem-like features. They show greater volume of expression of pluripotent transcription agents such as Lin28, Nanog, KLF4, Oct4, and Sox 2 in comparison to the respective adherent mono-layer cells [26, 60, 70, 71]. Moreover, influential expression of CSC specific markers, including CD44 and ALDH1 is expressed by oral tumor sphere-forming cells $[60,61,72]$. These would be largely tumorigenic as inoculated into nude mice and retain the respective selfrenovation capacities for several generations [72]. Table 1 listed oral cancer stem cell markers.

\section{Oral cancer stem cells and their signaling pathways}

CSCs have the shared features with normal stem cells and several certain traits maintaining tumor growth and invasion. One of the primary features of CSCs is their self-renewal capacities, so that it apparently is one of the motives to begin and maintain tumorigenicity [24]. CSCs Self-renewal may be retained through multiple endogenous signaling paths, including Wnt, Bmp,

Table 1 Oral cancer stem cell markers

\begin{tabular}{lll}
\hline Type of head and neck cancer & Marker & Refs \\
\hline HNSCC cell lines & ALDH & {$[73]$} \\
HNSCC cell lines & ZsGreen-CODC & {$[74]$} \\
HNSCC cell lines & CD10 & {$[75]$} \\
Nasopharyngeal SCC cell lines & Side population & {$[76]$} \\
Laryngeal SCC cell lines & CD133 & {$[77]$} \\
Glottic carcinoma biopsy & CD29 & {$[78]$} \\
Laryngeal SCC cell lines & CD44 & {$[79]$} \\
\hline
\end{tabular}


Pten, Notch, B cell-specific Moloney murine leukemia virus integration site 1 (Bmi1), TGF- $\beta$, and Hedgehog [80-86] that would be often actuated in human cancers $[85,87,88]$. A variety of signalling pathways and molecules could be involved in oral CSCs (Fig. 1). In the below, we have summarized some of them.
EMT

The CSCs unique feature is their metastatic potentials [24]. It has been found that EMT confers migratory potentials in cancer cells, and this procedure involves essentially in cancer metastasis. EMT is a procedure, through which epithelial cells would lose the respective properties for gaining mesenchymal phenotype, and therefore result in migrating and invading cells $[89,90]$. During EMT, expressing the epithelium-specific protein;

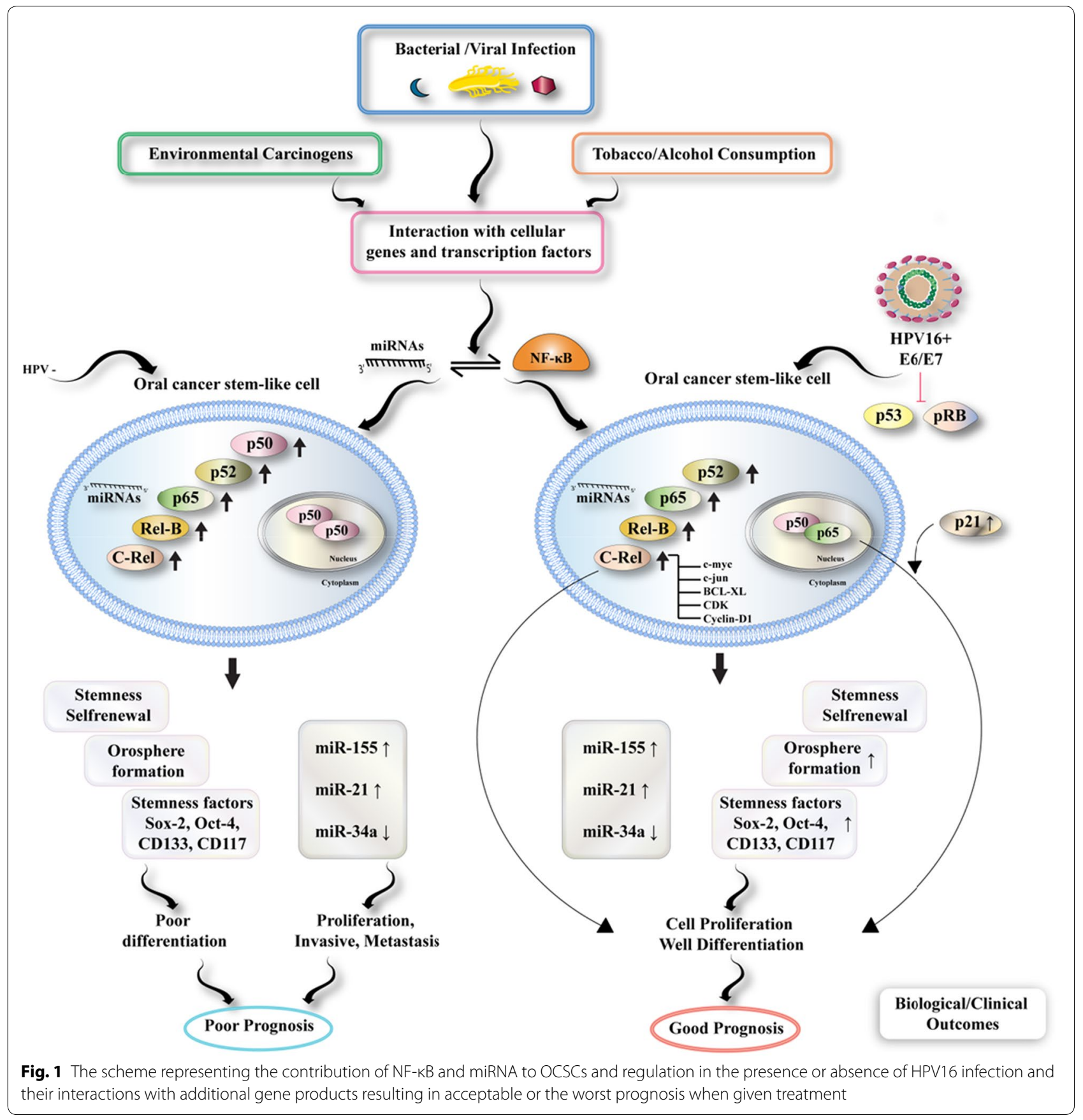


for example, cytokeratins and E-cadherin would decline, while expressing mesenchymal-specific proteins such as vimentin, fibronectin, and N-Cad increase. Researchers determined the major transcription parameters for EMT such as TWIST, LEF-1, SNAIL, and overexpressing these factors enhanced EMT [91, 92]. Fractionated CSCs would over-express EMT transcription factors, and considerably illustrate in vivo metastatic potentials in comparison with the ones in un-fractionated cancer cells, which suggests that cancer stem cells would be a key origin of the metastatic cancer cell population [93]. Additionally, some studies indicated vital contributions of the zincfinger E-box-binding homeobox (Zeb) to maintain the features of the EMT and cancer stem cells [94]. Zeb1 and Zeb2 remarkably enhanced cancer stem cells in the head and neck in comparison with the ones in non-CSCs [95]. Zeb1 and Zeb2 knock-down in the head and neck cancer cells diminished CSC features, including emigration, selfrenovation capacities, and stemness markers expressions. Furthermore, their inhibition suppressed growing in vivo tumor and level of metastasis to remote locations [95]. Contrarily, co-overexpressing Zeb1 and Zeb2 elevated the emigration capability of the head and neck cancer cells [95].

\section{$A B C$ transporters}

It is possible to enrich CSC population following chemoradiotherapy, which suggests that treatment leads to chemo-radioresistance, and or selectively improves the resistant cell population. Moreover, researchers documented different molecular determining factors for CSC chemo-radioresistance. However, they completely agreed that contribution of adenosine triphosphate (ATP)binding cassette $(\mathrm{ABC})$ transporters would be the major actors in resisting treatment [96]. $A B C$ transporters are the membrane transporters, which are capable of pumping different little molecules (e.g., anti-cancer medicines) out of the cells at the expense of ATP hydrolysis, and thus led to the decreased intra-cellular medicine concentrations. Overexpressing $\mathrm{ABC}$ transporters is one of the popular occurrences found in multi-drug resistance in cancers [97]. The increased levels of $A B C$ transporters are expressed by normal cells. Overexpressing $A B C$ transporters in cancer cells enhanced their chemo-radioresistance [98]. Suppressing ABC transporters elevates anti-cancer medicine sensitiveness in cancer [99]. The research usually indicated that $\mathrm{ABC}$ transporters are actually major molecular determining factors of CSC chemo-radioresistance. Little populations of CSCs that have higher efflux capacities because of the higher $A B C$ transporters are possibly isolated by treating the cells with Hoechst 33342 dye. Afterwards, they would be determined as a side population (SP). Several research revealed substantial separation of CSCs through the above method, and SP cells have higher capacitues for the CSC phenotype compared to the non-SP cells [100, 101]. Researchers also found the existence of SP cells in oral SP cells and oral cancer cells in comparison to the non-SP cells. They enhanced anti-cancer medicine resistance and the stem cell phenotype $[100,102,103]$. Hence, it is generally agreed that CSCs originally resist to chemo-radiotherapy and involve in tumor relapse [25].

\section{Inflammatory molecules}

As the abnormal actuation and over-expression of the pro-inflammatory transcription agent, NF- $\mathrm{kB}$ contributes importantly to the regulation of different cellular procedures such as apoptosis, cell differentiation, signal transduction paths, and transformation, particularly over the development and metastasis process of multiple cancers such as oral cancer, unpaving the contribution of NF-kB proteins is of high importance [104]. Studies revealed that the NF- $\kappa B$ path would be actuated commonly in the cancer and cancer stem cells of various malignances such as leukemia, ovary, breast, glioblastoma, pancreatic, prostate, and colon cancers. Notably, its actuation induces radiotherapy and chemotherapy resistance [105-107]. Additionally, miRNAs are still the other significant modulatory molecule engaged during carcinogenesis. They also may function as oncogenes or tumor inhibitor genes so that they practically interplay with NF- $\mathrm{kB}$ and additional molecules. However, there is not enough knowledge of the NF-kB and miRNA in strong relationship with crucial risks, alcohol, tobacco, and the increased risks of HPV infections during oral carcinogenesis and its prognoses. Bano et al. separated cancer stem-like SP cells from HPV \pm ve OSCC cell lines, and the main tumors, forming orospheres, which experienced expression of the stemness markers of Sox-2, Oct4, CD117, and CD133 [108]. The above cells exhibited differentially up-regulated expressing NF-kB proteins and selective over-expression of viral oncogenes E6/E7 just in HPV16 + ve cells that established greater numbers of orospheres, over-expressed c-Rel, and selectively actuated p65, which hetero-dimerized with p50 for showing greater DNA binding activities. Moreover, selective overexpressed miR-21 and miR-155 and down-regulation of miR-34a have been revealed via HPV + ve cancer stem cells overexpressing HPV16 oncogene E6, which have control over maintaining stemness. Although HPV-ve CSCs exhibit only p50 homo-dimeriztion, weak differentiations, and the worst prognoses, HPV infections involved participating p65 with de-regulated expression of certain miRNAs resulted in the detailed differentiation of tumors and more acceptable prognosis [108]. 


\section{Epigenetic regulators and oral cancer stem cells Histone demethylases}

Growing trend of documents show that various cancers such as oral cancers might be modulated in under epigenetic condition via histone demethylases or microRNAs [15, 61, 109-118]. One of the groups of histone demethylases epigenetically regulated transcribing gene via removal of the histone methylation marks [119]. Accordingly, histone demethylases contribute crucially to the dominating gene transcription via modifying chromatin availability and transcriptional machinery. Convincing documents demonstrated that histone demethylases involve in different cellular procedures such as carcinogenesis, cell fate selection, and cell differentiation [120-122]. Currently, the increasing trend of documents showed the essential contribution of histone demethylases such as JARID1, KDM4, LSD1, KDM6B, KDM6A, KMD3, KDM5, and Jumonji domain-consisting of protein 6 (JMJD6) to the cancer stem cell phenotype in several kinds of cancers [61, 123-130].

JMJD6 has been represented as a new molecular modulator of OCSCs [61]. JMJD6 is one of the histone arginine demethylases, which favorably eliminates methyl groups from dimethylated arginine 2 of histone 3 (H3R2me2) and arginine 3 of histone 4 (H4R3me2) [131]. Thus, it leads to the dynamic modulation of transcription. Moreover, JMJD6 modulates expressing gene via modulation of RNA splicing [132], which indicates that JMJD6 is a multi-faceted modulator of the gene expressions. A study showed that JMJD6 improves OSCC cancer stem cell populations; that is, tumor spheres and ALDH1 $1^{\mathrm{HIGH}}$ cell population in comparison with the oral stem cancer cells non-cancer stem cell populations, including adherent mono-layer cells and ALDH $1{ }^{\text {low }}$ cell population [61]. It has been shown that silencing JMJD6 caused losing self-renovation potential, migration capability, and chemoresistance in OSCC cells. Moreover, reports indicated that JMJD6 knockdown in aggressive breast cancer cell lines declined cell emigration; however, its over-expression augmented cellular motility [133]. There is an interaction between JMJD6 and the splicing factor U2AF65. JMJD6 regulates alternate splicing of vascular EGF (VEGF) receptor [132]. Moreover, results demonstrated that alternate splicing of the VEGF receptor via U2AF65 enhanced endothelial cell emigration, and JMJD6 silencing in the endothelial cells caused lower emigration [134]. Hence, it is necessary to determine the impacts of JMJD6 on EMT. Contrarily, overexpressing JMJD6 increases both the CSC traits and the numbers of CSCs, which suggests that JMJD6 is a prominent modulator of the cancer stem cell phenotype and genesis in OSCC.

\section{MicroRNAs}

The increased trend of investigations reflected the utilization of the noncoding RNAs as the upstream regulator of the CSCs using diverse systems like EMT regulation [135, 136].

In fact, the non-coding RNAs represent the RNA, which would not encode a protein and thus may be categorized into multiple groups like the long non-coding RNAs (lncRNAs = above 200 nucleotides in length) and small non-coding RNAs (like microRNAs =approximately 19 to 22 nucleotides in length) [137-141]. Finally, it has been found that that microRNAs (miRNAs) regulated translational effectiveness or stability of the targeted mRNAs via interactions with $3^{\prime}$-un-translated region ( $3^{\prime}$-UTR) of the respective targets [142-147]. These molecules exert their effects via targeting a variety of molecular and cellular mechanisms [148-152]. Hence, miRNAs could be used as diagnostic, prognostic and therapeutic biomarkers in the treatment of different diseases such as stroke, cancer, cardiovascular diseases, infection diseases, diabetes, and viral infections [153-163].

There is evidence of the significant down-regulation of miR-200c expression in the $\mathrm{ALDH} 1^{+} / \mathrm{CD} 44^{+} \mathrm{HNSCC}$ with greater BMI1 expression level [164]. In addition, researchers demonstrated possible significant inhibition of malignant CSC features or BMI1 knock-down by upregulating the miR-200c could so that ZEB1 or ZEB2 knockdown may enhance the miR-200c and suppress the BMI1 expressions in the ALDH $1^{+} / \mathrm{CD} 44^{+}$HNSCC cells, which revealed that interactions between ZEB1/ ZEB2, BMI1, and miR-200c detected the fate of the cancer stemness in OSCC. Put differently, one of the popular tumor repressors called p53 could attach to the promoter area of the miR-200c at several locations [164]. Moreover, researchers approved that as a most repeatedly in-activated tumor inhibitor gene in HNSCC, losing the level of p53 expression correlated to metastatic ability of HNSCC $[165,166]$. Finally, p53 mutation could contribute to down-stream transcriptional actuation of the miR-200c, which enhanced the CSC features.

In addition, some studies showed that $\mathrm{ALDH} 1^{+} \mathrm{CD} 44^{+}$ HNSCC cells expressed lower level of miR145 and thus inhibiting miR-145 has been adequate for driving the tumor-inducing characteristics in the $\mathrm{ALDH} 1^{-} \mathrm{CD} 44^{-}$ HNSCC cells [167]. Therefore, the miR-145 could experience a direct binding to the ADAM17 and SOX9 through their $3^{\prime}$-UTR areas. Consequently, analysis showed that SOX9 directly modulated the ADAM17 promoter and this SOX9/ADAM17 axis determined miR-145-mediated CSC and EMT and features. As a result, that mediation of IL- 6 and soluble IL- 6 receptor secretion by the miR145-ADAM17 pathway has been revealed that could played a role in maintaining the CSC characteristics in 
a paracrine way. Curcumin is a natural compounds that could be used in the treatment of different diseases such as cancer [168-175]. The curcumin delivery attenuated the tumor expansion in vivo by enhancing the miR-145 promoter activities [167].

\section{Calcium channels}

Recently, authors proposed the significance of calcium signaling in modulating oral cancer stemness traits [60, $176-178] . \mathrm{Ca}^{2+}$ is one of the global second messengers regulating several physiological procedures, and disruption of its homeostasis would be observed during carcinogenesis, which results in the deregulation of the rapid growth of the cells, emigration, and apoptosis inhibition [179-182]. In a majority of the nonexcitable cells, it has been found that $\mathrm{Ca}^{2+}$ influx is strongly modulated via the store-operated $\mathrm{Ca}^{2+}$ entry (SOCE) path, and mediated by store-operated $\mathrm{Ca}^{2+}$ release-actuated $\mathrm{Ca}^{2+}$ (CRAC) channels [183]. Research revealed that Orail is one of the crucial pore subunits of CRAC channels [184-186]. When the cells stimulated, they experience releasing $\mathrm{Ca}^{2+}$ from the endoplasmic reticulum (ER), accompanied by extra-cellular $\mathrm{Ca}^{2+}$ influx via SOCE. However, it should be stated that SOCE both re-fills the depleted ER $\mathrm{Ca}^{2+}$ stores and presents a direct $\mathrm{Ca}^{2+}$ signal for activating down-stream responses such the nuclear factor of the actuated T-cells (NFAT) signaling path [187, 188]. Researchers have widely examined Orai1 in immunology, because NFAT is a transcription agent with a vital role to activate, differentiate, and effector functions of T-cells [189]. Results indicated essential contribution of Orai1 to carcinogenesis [60, 177, 181, 190-197].

Higher expression of Orai1 is observed in cancer stem cells-improved cell population, including tumor spheres and ALDH1 ${ }^{\mathrm{HIGH}}$ population of OSCC [60]. Moreover, Orai1 is capable of endowing non-tumorigenic immortalized oral epithelial cells with self-renovation, and concurrently enhances transcribing pluripotent and cancer stem cells-associated agents such as Nanog, Sox2, KLF4, Oct4, Zeb1, Bmi1, and Zeb2. Studies also illustrated that $\mathrm{ALDH} 1^{+}$cancer stem cells population in non-tumorigenic oral epithelial cells is increased by expressing ectopic Orail, which enhances OSCC metastatic potentials. This result agrees with the other publications representing the significance of Orail in the emigration capability of invasive breast cancer cells [133]. Suppressing Orai1 in numerous OSCC cell lines resulted in suppressing CSC traits. Therefore, our hypothesis is that Orai1 would promote malignant development of OSCC via enrichment of the CSC phenotype. Yet, there is not enough knowledge of the basic mechanism, through which Orai1 modulates oral cancer stemness.
NFAT is a major down-stream objective of Orai1mediated $\mathrm{Ca}^{2+}$. It is de-phosphorylated via a protein phosphatase complex containing calcineurin and calmodulin $[198,199]$. researchers found important contribution of NFAT for maintaining CSCs in human cancers like melanoma pancreatic, colonic, and lung [200-203]. In addition, researchers showed that silencing NFATc3 in the cells having an overexpressed ectopic Orail in OSCC cells caused inhibiting CSC phenotype. Moreover, an NFAT chemical suppressor substantially suppressed cancer stemness in cells. Thus, NFATc 3 would be necessary for the Orail-induced CSC phenotype, indicating practical contribution of the Orail/NFATc3 axis to the oral CSC modulation.

$\mathrm{Ca}^{2+}$ oscillation (spatio-temporal modulation calcium signaling) is more crucial compared to the overall modifications in cytosolic $\mathrm{Ca}^{2+}$ concentrations in the area of tumor invading nature, progression, and cancer stemness [176-178]. $\mathrm{Ca}^{2+}$ oscillation is the final outcome of Orai1mediated SOCE so that Orail would be improved in OCSCs. As suppressing Orail channel performance led to the complete shut-down of $\mathrm{Ca}^{2+}$ oscillation in OSCC cells, Orai1-mediated $\mathrm{Ca}^{2+}$ oscillation might be a potent selective target to treat oral CSCs.

\section{Other mechanisms}

From among the above pathways, researchers largely confirmed contribution Bmil and Notch signaling in oral cancer stemness. Activating the Notch1 signaling pathway is necessary to maintain cancer stem cells, and demands attachment of its ligands Jagged 1 (JAG1), JAG 2 , and $\delta$-like, accompanied by the proteolytic releases of the Notch intra-cellular domain (NICD), and activating NICD down-stream target genes [204]. We formerly stated that if the OSCC cells are exposed to the proinflammatory cytokine TNF $\alpha$ in the long term, they augment self-renovation capacities and tumorigenicity that is related to the actuation of the Notch path [62]. It has been also found that Hes1 in TNF $\alpha$-induced oral cancer stemness is the objective of the actuated Notch1 so that its knock-down inhibits self-renewing potential of TNF $\alpha$-treated OSCC cells. Expression of Hes1 is usually performed in multiple un-differentiated cell kinds in the growing mouse embryo. It also contributes critically to maintain progenitor cell fate. Data obtained from the studies showed that Hes1-deficient mice exhibited pre-mature differentiation, subsequent lethality, and progenitor cell depletion [205]. In total, the above results suggested that Notch1-Hes1 axis is one of the newly designed axes to regulate oral CSCs self-renewal.

Bmil that is one of members of the polycomb group transcription repressors involves in oral cancer [206, 207]. Recently, researchers revealed the essential 
contribution of Bmi1 to maintenance of the self-renewal capacities of oral CSCs $[208,209]$. In addition, in a case of the use of the genetic lineage tracing, in vivo contribution of Bmil to regulate the stemness of oral cancer stem cells such as its self-renewal and tumorigenic potentials has been obviously illustrated [209].

\section{Oral cancer stem cell therapy}

Cancer therapy is very important aspect in the public health field [210-212]. Many researchers developed a variety of therapeutic approaches such as immune cell therapy, stem cell therapy, gene therapy, nanotechnology-based therapy, and utilization of natural compounds in the treatment of various cancers [213-219]. In this regards, several fields emphasize the identification and specific targeting of the neck and neck CSCs (Table 2) [220]. However, the new therapeutic regimes carried considerable morbidities like defacement and functional modifications from surgical operations to the systemic toxicity caused by chemo-therapy as well as radiation-induced consequences due to radio-therapy. In addition, as a result of diverse innate systems, the CSCs frequently resisted to the conventional radiation and chemo-therapy. Such cells have been capable of surviving through treatment and repopulating the tumors with the chemo-radioresistant cells. thus, the specifically targeting head and neck CSCs provided a potent device of the ameliorated cancer outputs by demonstrating the organ conservation and declining the off-target toxicity [220].

As seen in the literature, CD44 is one of the wellknown exploration targets for the targeted therapies against CSCs. In fact, researchers utilized hyaluronic acid (with its selective binding to CD44) as one of the agents to deliver the directed treatments as opposed to the CD44 positive cells like the hyaluronic acid conjugated chemo-therapeutics as well as the hyaluronic acid guided NPS. Moreover, hyaluronic acid induced the interactions between CD44 and the stem cell transcription factors Nanog, Sox2, and Oct-4 [58]. Thus, additional investigations should be performed for showing advantages of the hyaluronic acid targeting with any induction of more activation of the CSCs. Consequently, experts in the field explored the anti-CD133 treatments as the targeted head and neck anti-CSC therapies. One of the studies on the bacterial toxin (cyto-lethal distending toxin) to an antihuman CD133 monoclonal antibody revealed inhibiting the cells proliferation while other investigation, which utilized a single-chain variable fragment targeting CD133 demonstrated remarkable diminishment in the rapid growth of the tumors in the cells and rat models [221,

Table 2 Cancer stem cell targeting in head and neck cancer

\begin{tabular}{|c|c|c|c|c|}
\hline Therapeutic target & Compound & Mechanism & Model & References \\
\hline Nanog & Silencing & Suppresses tumorigenic and CSCs-like abilities & In vitro & [226] \\
\hline Grp78 & Silencing & $\begin{array}{l}\text { Inhibits tumor growth and stem cell regulatory } \\
\text { proteins i.e., slug and Oct-4 }\end{array}$ & In vitro & [225] \\
\hline CD44 & Silencing & $\begin{array}{l}\text { Decreases migration, EMT, and reduces the expres- } \\
\text { sion of snail, vimentin, N-cadherin and slug }\end{array}$ & In vitro & [232] \\
\hline Inhibiting translation elongation & SVC112 & $\begin{array}{l}\text { Increases the progression of cell-cycle slows and } \\
\text { delay DNA repair following radiation. Improves } \\
\text { colony and sphere formation }\end{array}$ & In vitro & [233] \\
\hline Let-7d/CDC34 axis & Niclosamide & Induces cell cycle arrest in G1 phase & In vitro, in vivo & [234] \\
\hline $5 \mathrm{~T} 4$ & MEDI0641 & Decreases the CSC fraction, and tumor regression & In vivo & [235] \\
\hline cMET/FZD8 & PF-2341066 & $\begin{array}{l}\text { Decreases tumor initiation, sphere formation, and } \\
\text { metastatic spread }\end{array}$ & In vivo & {$[236]$} \\
\hline CD44v6 & $\begin{array}{l}\text { Anti-CD44v6 antibody } \\
\text { BIWA-IRDye800CW and } \\
\text {-Indium-111 }\end{array}$ & Detection of tumor regions and invasive zones & In vivo & [237] \\
\hline CD44 & Radionuclide ${ }^{186} \operatorname{Re}-\mathrm{cmAb}(\mathrm{U} 36)$ & $\begin{array}{l}\text { Dose-limiting myelotoxicity, reduction in tumor } \\
\text { size }\end{array}$ & Human & [238] \\
\hline ALDH1 & Alda-89, Aldi-6 & $\begin{array}{l}\text { In combination with cisplatin improves apoptosis } \\
\text { and decreases tumor growth }\end{array}$ & In vitro, in vivo & [239] \\
\hline Porcupine (PORCN) (Wnt signaling) & LGK974 & $\begin{array}{l}\text { High response in HNSCC with Notch loss of func- } \\
\text { tion mutation }\end{array}$ & In vitro & [240] \\
\hline FGF & BGJ398 & $\begin{array}{l}\text { Reduces ALDH }{ }^{\text {high }} C D 44^{\text {high }} \text {, sensitization to } \\
\text { cisplatin }\end{array}$ & In vitro & [241] \\
\hline Bmi1/AP-1 & PTC-209 & $\begin{array}{l}\text { Cisplatin plus PTC- } 209 \text { potently eradicates } \\
\text { Bmi } 1+\text { CSCs and suppresses progression of } \\
\text { tumor }\end{array}$ & In vitro & [209] \\
\hline
\end{tabular}


222]. As a result, CD271 inhibited in the cell models for decreasing the formation of the tumors [223]. Finally, one of the encouraging options to treat this condition would be targeting the CSC surface markers and the best performance in relation to the remaining treatments would be as a delivery mechanism.

Notably, one of the main today's investigation fields is the addition of the novel agents or targeted treatment related to the standard cisplatin chemo-therapy. Moreover, salino-mycin with paclitaxel and cisplatin functioned for increasing apoptosis in the neck and neck CSCs [224]. Additionally, GRP78 has been considered to be one of the multi-functional protein contributed to the cell survival as well as resistance to chemo-therapy. Inhibiting the GRP78 would sensitize the head and neck CSCs for radiation and chemotherapy [225]. In this regard, Huang et al. revealed the greater sensitivity to cisplatin by small hairpin RNA knock-down of Nanog [226]. Furthermore, researchers indicated that CSCs had lower levels of ROS, assisting in the maintenance of the stem-like features and chemo-resistance. Finally, inhibiting the ROS scavenging proteins (SOD2 \& Catalase) enhanced the ROS and the following enhancement in the sensitivity to cisplatin [227].

Experts in the field are growingly applying the epidermal growth factor receptor (EGFR) inhibition (with cetuximab) in the advanced and recurring HNSCC therapeutic guidelines. The former investigations also suggested the potent contribution to the EGFR targeted treatment especially as opposed to the head and neck CSCs. However, in the naso-pharyngeal carcinomas, EGFR acted using CTNNB1 and $A K T$ pathways for driving the CSC phenotypes [228]. Moreover, activating EGFR in the head and neck CSCs enhanced expressing the genes engaged in the CSC rapid growth or proliferation (OCT4, BMI1, CD44, NANOG) and CSCs treatment through inhibiting EGFR declined the tumor growth and augmented the sensitivity to cisplatin [228].

Greater abilities for the efflux cytotoxic agents have been considered as one of the main devices of CSC resistance to chemo-therapy. Therefore, researchers examined the cellular efflux proteins as the potent targets to sensitize the CSCs to the current chemo-therapy agents. Earlier research on the laryngeal cancer cell-lines diminished the CSC proportion by verapamil that is one of the inhibitors to the ABCG2 membrane transporter [229]. It is notable that suppressors to other members of $A B C$ transporter family in case of application to the head and neck and CSC populations, enhanced sensitivity to the chemo-therapy [230]. Moreover, authors largely explored the enhanced CSC sensitivity to the radiation. However, today's examinations target ATRA (a retinoid involved in cell terminal differentiation) and CHEK1/2 DNA damage repair genes in the head and neck CSCs. Such explorations demonstrate greater responses to the radiation in the CSCs following the CHEK1/2 suppression and ATRA utilization [79]. Finally, inhibiting the SHH/MTOR/ RPS6KB1 pathways augmented radio-sensitivity to CSCs, reflecting the contribution of the above pathways and potent targetable choices to enhance the CSC radio-sensitivity [231].

\section{Conclusion}

One of very important players in the initiation, and progression of cancer are CSCs. A variety of reports documented that these sub-populations of cancer cells are associated to different properties of cancer such as metastasis, tumorigenicity, and recurrence. Hence, CSCs are known as the root of the cancer. Moreover, targeting the CSCs would be one of the encouraging as well as evasive treatment options, which aimed to enhance efficacy and specificity for eradicating the tumors and declining the systemic or off-target toxicity. Consequently, investigations of the additional description and targeted treatments towards the head and neck CSCs would be one of the active and fast growing fields. Given that CSCs exert their tumorigenesis roles via affecting on a sequencing of cellular and molecular targets and pathways (i.e., microRNAs, histone modifications and calcium regulations). Therefore, more and better understanding of CSCs actions can provide unique opportunities to develop new therapeutic platforms for targeting CSCs in the treatment of various cancers.

\section{Abbreviations}

ABC: (ATP)-binding cassette; ALDH1: Aldehyde dehydrogenase1; CRAC: $\mathrm{Ca}^{2+}$ release-actuated $\mathrm{Ca}^{2}$; CSCs: Cancer stem cells; EGF: Epidermal growth factor; EMT: Epithelial-mesenchymal transition; ESA: Epithelial-specific antigen; iPSCs: Induced pluripotent stem cells; JAG1: Jagged 1; HMLEs: Human mammary epithelial cells; HNSCC: Head and neck squamous cell carcinoma; NFAT: Nuclear factor of the actuated T-cells; NICD: Notch intra-cellular domain; OSCC: Oral squamous cell carcinoma; SC: Stem cell; SCID: Severe combined immunedeficient; Zeb: Zinc-finger E-box-binding homeobox.

\section{Acknowledgements}

Not applicable.

\section{Authors' contributions}

$\mathrm{RKH}$ involved in conception, design, statistical analysis and drafting of the manuscript. GB and FM contributed in data collection and manuscript drafting. All authors read and approved the final manuscript.

\section{Funding}

The present study was founded by a grant from the Vice Chancellor for Research, Tehran University of Medical Sciences, in Iran.

Availability of data and materials

The primary data for this study is available from the authors on direct request.

Ethics approval and consent to participate

This study was considered exempt by the TUMS Institutional Review Board. 


\section{Consent for publication \\ Not applicable.}

\section{Competing interests}

The authors declare that they haveno comprting interests.

\section{Author details}

${ }^{1}$ Department of Pediatric Dentistry, School of Dentistry, Tehran University of Medical Sciences, Tehran, Iran. ${ }^{2}$ Department of Pediatric Dentistry, School of Dentistry, Zahedan University of Medical Sciences, Zahedan, Iran.

Received: 2 January 2020 Accepted: 27 March 2020

Published online: 07 April 2020

\section{References}

1. Bray F, Ferlay J, Soerjomataram I, Siegel RL, Torre LA, Jemal A. Global cancer statistics 2018: GLOBOCAN estimates of incidence and mortality worldwide for 36 cancers in 185 countries. CA Cancer J Clin. 2018;68:394-424.

2. Siegel RL, Miller KD. Cancer statistics. CA Cancer J Clin. 2020;2020(70):7-30.

3. Gatta G, Botta L, Sanchez MJ, Anderson LA, Pierannunzio D, Licitra L. Prognoses and improvement for head and neck cancers diagnosed in Europe in early 2000s: The EUROCARE-5 population-based study. Eur J Cancer. 2015;51:2130-43.

4. Beynon RA, Lang S, Schimansky S, Penfold CM, Waylen A, Thomas SJ, Pawlita M, Waterboer T, Martin RM, May M, Ness AR. Tobacco smoking and alcohol drinking at diagnosis of head and neck cancer and all-cause mortality: results from head and neck 5000, a prospective observational cohort of people with head and neck cancer. Int J Cancer. 2018:143:1114-27.

5. Marziliano A, Teckie S, Diefenbach MA. Alcohol-related head and neck cancer: summary of the literature. Head Neck. 2019

6. Paver EC, Currie AM, Gupta R, Dahlstrom JE. Human papilloma virus related squamous cell carcinomas of the head and neck: diagnosis, clinical implications and detection of HPV. Pathology. 2020;52:179-91.

7. Ramesh PS, Devegowda D, Singh A, Thimmulappa RK. NRF2, p53, and p16: predictive biomarkers to stratify human papillomavirus associated head and neck cancer patients for de-escalation of cancer therapy. Crit Rev Oncol Hematol. 2020;148:102885.

8. Berglund BA, Boring DL, Howlett AC. Investigation of structural analogs of prostaglandin amides for binding to and activation of CB1 and CB2 cannabinoid receptors in rat brain and human tonsils. Adv Exp Med Biol. 1999:469:527-33.

9. Zhu LX, Sharma S, Stolina M, Gardner B, Roth MD, Tashkin DP, Dubinett SM. Delta-9-tetrahydrocannabinol inhibits antitumor immunity by a CB2 receptor-mediated, cytokine-dependent pathway. J Immunol. 2000;165:373-80

10. McKallip RJ, Nagarkatti M, Nagarkatti PS. Delta-9-tetrahydrocannabinol enhances breast cancer growth and metastasis by suppression of the antitumor immune response. J Immunol. 2005;174:3281-9.

11. Gillison ML, D'Souza G, Westra W, Sugar E, Xiao W, Begum S, Viscidi R. Distinct risk factor profiles for human papillomavirus type 16-positive and human papillomavirus type 16-negative head and neck cancers. J Natl Cancer Inst. 2008:100:407-20.

12. Warnakulasuriya S, Reibel J, Bouquot J, Dabelsteen E. Oral epithelial dysplasia classification systems: predictive value, utility, weaknesses and scope for improvement. J Oral Pathol Med. 2008;37:127-33.

13. Brennan M, Migliorati CA, Lockhart PB, Wray D, Al-Hashimi I, Axéll T, Bruce AJ, Carpenter W, Eisenberg E, Epstein JB. Management of oral epithelial dysplasia: a review. Oral Surg Oral Med Oral Pathol Oral Radiol Endodontol. 2007;103:S19e11-2.

14. Mohammadi M, Jaafari MR, Mirzaei HR, Mirzaei H. Mesenchymal stem cell: a new horizon in cancer gene therapy. Cancer Gene Ther. 2016;23:285-6.

15. Mirzaei H, Sahebkar A, Sichani LS, Moridikia A, Nazari S, Sadri Nahand J, Salehi H, Stenvang J, Masoudifar A, Mirzaei HR, Jaafari MR. Therapeutic application of multipotent stem cells. J Cell Physiol. 2018;233:2815-23.
16. Mirzaei H, Sahebkar A, Avan A, Jaafari MR, Salehi R, Salehi H, Baharvand H, Rezaei A, Hadjati J, Pawelek JM, Mirzaei HR. Application of mesenchymal stem cells in melanoma: a potential therapeutic strategy for delivery of targeted agents. Curr Med Chem. 2016;23:455-63.

17. Mirzaei HR, Sahebkar A, Salehi R, Nahand JS, Karimi E, Jaafari MR, Mirzaei $H$. Boron neutron capture therapy: moving toward targeted cancer therapy. J Cancer Res Ther. 2016;12:520-5.

18. Hashemi Goradel N, Ghiyami-Hour F, Jahangiri S, Negahdari B, Sahebkar A, Masoudifar A, Mirzaei H. Nanoparticles as new tools for inhibition of cancer angiogenesis. 2018;233:2902-10.

19. Stoopler ET, Sollecito TP. Oral Cancer. Dent Clin North Am. 2018;62:9-10.

20. Mirzaei H, Sahebkar A, Jaafari MR, Hadjati J, Javanmard SH, Mirzaei HR, Salehi R. PiggyBac as a novel vector in cancer gene therapy: current perspective. Cancer Gene Ther. 2016;23:45-7.

21. Hesari A, Azizian M, Sheikhi A, Nesaei A, Sanaei S, Mahinparvar N, Derakhshani M, Hedayt P, Ghasemi F, Mirzaei H. Chemopreventive and therapeutic potential of curcumin in esophageal cancer: current and future status. 2019;144:1215-26.

22. Keshavarzi M, Darijani M. Molecular imaging and oral cancer diagnosis and therapy. J Cell Biochem. 2017;118:3055-60.

23. Marcial VA, Pajak TF, Mohiuddin M, Cooper JS, AI Sarraf M, Mowry PA, Curran W, Crissman J, Rodríguez M, Vélez-Garca E. Concomitant cisplatin chemotherapy and radiotherapy in advanced mucosal squamous cell carcinoma of the head and neck. Long-term results of the Radiation Therapy Oncology Group study 81-17. Cancer. 1990;66:1861-8.

24. Beck B, Blanpain C. Unravelling cancer stem cell potential. Nat Rev Cancer. 2013;13:727.

25. Nassar D, Blanpain C. Cancer stem cells: basic concepts and therapeutic implications. Annu Rev Pathol. 2016;11:47-76.

26. Chiou S-H, Yu C-C, Huang C-Y, Lin S-C, Liu C-J, Tsai T-H, Chou S-H, Chien $\mathrm{C}-\mathrm{S}, \mathrm{Ku} \mathrm{H}-\mathrm{H}$, Lo J-F. Positive correlations of Oct-4 and Nanog in oral cancer stem-like cells and high-grade oral squamous cell carcinoma. Clin Cancer Res. 2008;14:4085-95.

27. Ginestier C, Hur MH, Charafe-Jauffret E, Monville F, Dutcher J, Brown M, Jacquemier J, Viens P, Kleer CG, Liu S. ALDH1 is a marker of normal and malignant human mammary stem cells and a predictor of poor clinical outcome. Cell Stem Cell. 2007;1:555-67.

28. Grimm M, Krimmel M, Polligkeit J, Alexander D, Munz A, Kluba S, Keutel C, Hoffmann J, Reinert S, Hoefert S. ABCB5 expression and cancer stem cell hypothesis in oral squamous cell carcinoma. Eur J Cancer. 2012;48:3186-97.

29. Hayashi S, Tanaka J, Okada S, Isobe T, Yamamoto G, Yasuhara R, Irie T, Akiyama C, Kohno Y, Tachikawa T. Lin28a is a putative factor in regulating cancer stem cell-like properties in side population cells of oral squamous cell carcinoma. Exp Cell Res. 2013;319:1220-8.

30. Richard V, Sebastian P, Nair MG, Nair SN, Malieckal TT, Kumar TS, Pillai MR. Multiple drug resistant, tumorigenic stem-like cells in oral cancer. Cancer Lett. 2013;338:300-16.

31. Zhang Q, Shi S, Yen Y, Brown J, Ta JQ, Le AD. A subpopulation of CD $133^{+}$cancer stem-like cells characterized in human oral squamous cell carcinoma confer resistance to chemotherapy. Cancer Lett. 2010;289:151-60.

32. Felthaus O, Ettl T, Gosau M, Driemel O, Brockhoff G, Reck A, Zeitler K Hautmann M, Reichert T, Schmalz G. Cancer stem cell-like cells from a single cell of oral squamous carcinoma cell lines. Biochem Biophys Res Commun. 2011:407:28-33.

33. Bonnet D, Dick JE. Human acute myeloid leukemia is organized as a hierarchy that originates from a primitive hematopoietic cell. Nat Med. 1997;3:730.

34. Prince M, Sivanandan R, Kaczorowski A, Wolf G, Kaplan M, Dalerba P, Weissman I, Clarke M, Ailles L. Identification of a subpopulation of cells with cancer stem cell properties in head and neck squamous cell carcinoma. Proc Natl Acad Sci. 2007;104:973-8.

35. Singh SK, Clarke ID, Terasaki M, Bonn VE, Hawkins C, Squire J, Dirks PB. Identification of a cancer stem cell in human brain tumors. Cancer Res. 2003:63:5821-8.

36. Patrawala L, Calhoun T, Schneider-Broussard R, Li H, Bhatia B, Tang S, Reilly J, Chandra D, Zhou J, Claypool K. Highly purified CD44+ prostate cancer cells from xenograft human tumors are enriched in tumorigenic and metastatic progenitor cells. Oncogene. 2006;25:1696. 
37. Li C, Heidt DG, Dalerba P, Burant CF, Zhang L, Adsay V, Wicha M, Clarke MF, Simeone DM. Identification of pancreatic cancer stem cells. Cancer Res. 2007;67:1030-7.

38. Mackenzie IC. Growth of malignant oral epithelial stem cells after seeding into organotypical cultures of normal mucosa. J Oral Pathol Med. 2004;33:71-8

39. Todoroki K, Ogasawara S, Akiba J, Nakayama M, Naito Y, Seki N, Kusukawa J, Yano H. CD44v3+/CD24-cells possess cancer stem celllike properties in human oral squamous cell carcinoma. Int J Oncol. 2016:48:99-109.

40. Ghuwalewala S, Ghatak D, Das P, Dey S, Sarkar S, Alam N, Panda CK, Roychoudhury S. CD44 ${ }^{\text {high }} \mathrm{CD} 24^{\text {low }}$ molecular signature determines the cancer stem cell and EMT phenotype in oral squamous cell carcinoma. Stem Cell Res. 2016;16:405-17.

41. Pastrana E, Silva-Vargas V, Doetsch F. Eyes wide open: a critical review of sphere-formation as an assay for stem cells. Cell Stem Cell. 2011;8:486-98.

42. Shrivastava S, Steele R, Sowadski M, Crawford SE, Varvares M, Ray RB. Identification of molecular signature of head and neck cancer stem-like cells. Sci Rep. 2015;5:7819.

43. Zhang Z, Sant'Ana Filho M, Nör JE. The biology of head and neck cancer stem cells. Oral Oncol. 2012:48:1-9.

44. Eun K, Ham SW, Kim H. Cancer stem cell heterogeneity: origin and new perspectives on CSC targeting. BMB Rep. 2017:50:117.

45. Prasetyanti PR, Medema JP. Intra-tumor heterogeneity from a cancer stem cell perspective. Mol Cancer. 2017;16:41.

46. Yan Y, Zuo X, Wei D. Concise review: emerging role of CD44 in cancer stem cells: a promising biomarker and therapeutic target. Stem Cells Transl Med. 2015;4:1033-43.

47. Wang L, Zuo X, Xie K, Wei D. The role of CD44 and cancer stem cells. cancer stem cells. Berlin: Springer; 2018. p. 31-42.

48. Al-Hajj M, Wicha MS, Benito-Hernandez A, Morrison SJ, Clarke MF. Prospective identification of tumorigenic breast cancer cells. Proc Natl Acad Sci. 2003;100:3983-8.

49. Tomita H, Tanaka K, Tanaka T, Hara A. Aldehyde dehydrogenase $1 \mathrm{~A} 1$ in stem cells and cancer. Oncotarget. 2016;7:11018.

50. Ota N, Ohno J, Seno K, Taniguchi K, Ozeki S. In vitro and in vivo expression of aldehyde dehydrogenase 1 in oral squamous cell carcinoma. Int J Oncol. 2014;44:435-42.

51. Clay MR, Tabor M, Owen JH, Carey TE, Bradford CR, Wolf GT, Wicha MS, Prince ME. Single-marker identification of head and neck squamous cell carcinoma cancer stem cells with aldehyde dehydrogenase. Head Neck. 2010;32:1195-201.

52. Yoshida A. Molecular genetics of human aldehyde dehydrogenase. Pharmacogenetics. 1992;2:139-47.

53. Neumeister V, Agarwal S, Bordeaux J, Camp RL, Rimm DL. In situ identification of putative cancer stem cells by multiplexing ALDH1, CD44, and cytokeratin identifies breast cancer patients with poor prognosis. Am J Pathol. 2010;176:2131-8.

54. Chen Y-C, Chen Y-W, Hsu H-S, Tseng L-M, Huang P-I, Lu K-H, Chen D-T, Tai L-K, Yung M-C, Chang S-C. Aldehyde dehydrogenase 1 is a putative marker for cancer stem cells in head and neck squamous cancer. Biochem Biophys Res Commun. 2009;385:307-13.

55. Prince ME, Zhou L, Moyer JS, Tao H, Lu L, Owen J, Egenti M, Zheng F, Chang AE, Xia J. Evaluation of the immunogenicity of ALDHhigh human head and neck squamous cell carcinoma cancer stem cells in vitro. Oral Oncol. 2016:59:30-42.

56. Rae C, Tesson M, Babich JW, Boyd M, Sorensen A, Mairs RJ. The role of copper in disulfiram-induced toxicity and radiosensitization of cancer cells. J Nucl Med. 2013;54:953-60.

57. Keymoosi H, Gheytanchi E, Asgari M, Shariftabrizi A, Madjd Z. ALDH1 in combination with CD44 as putative cancer stem cell markers are correlated with poor prognosis in urothelial carcinoma of the urinary bladder. Asian Pac J Cancer Prev. 2014;15:2013-20.

58. Bourguignon LY, Wong G, Earle C, Chen L. Hyaluronan-CD44v3 interaction with Oct4-Sox2-Nanog promotes miR-302 expression leading to self-renewal, clonal formation, and cisplatin resistance in cancer stem cells from head and neck squamous cell carcinoma. J Biol Chem. 2012;287:32800-24.

59. Wang $Y, Y u$ Y, Tsuyada A, Ren $X$, Wu X, Stubblefield K, RankinGee EK, Wang SE. Transforming growth factor- $\beta$ regulates the sphere-initiating stem cell-like feature in breast cancer through miRNA-181 and ATM. Oncogene. 2011;30:1470.

60. Lee SH, Rigas NK, Lee C-R, Bang A, Srikanth S, Gwack Y, Kang MK, Kim RH, Park N-H, Shin K-H. Orai1 promotes tumor progression by enhancing cancer stemness via NFAT signaling in oral/oropharyngeal squamous cell carcinoma. Oncotarget. 2016;7:43239.

61. Lee C-R, Lee SH, Rigas NK, Kim RH, Kang MK, Park N-H, Shin K-H. Elevated expression of JMJD6 is associated with oral carcinogenesis and maintains cancer stemness properties. Carcinogenesis. 2015;37:119-28.

62. Lee SH, Hong HS, Liu ZX, Kim RH, Kang MK, Park N-H, Shin K-H. TNFa enhances cancer stem cell-like phenotype via Notch-Hes1 activation in oral squamous cell carcinoma cells. Biochem Biophys Res Commun. 2012;424:58-64.

63. Cao L, Zhou Y, Zhai B, Liao J, Xu W, Zhang R, Li J, Zhang Y, Chen $\mathrm{L}$, Qian $\mathrm{H}$. Sphere-forming cell subpopulations with cancer stem cell properties in human hepatoma cell lines. BMC Gastroenterol. 2011;11:71

64. Gibbs CP, Kukekov VG, Reith JD, Tchigrinova O, Suslov ON, Scott EW, Ghivizzani SC, Ignatova TN, Steindler DA. Stem-like cells in bone sarcomas: implications for tumorigenesis. Neoplasia. 2005;7:967-76.

65. Fujii H, Honoki K, Tsujiuchi T, Kido A, Yoshitani K, Takakura Y. Sphereforming stem-like cell populations with drug resistance in human sarcoma cell lines. Int J Oncol. 2009;34:1381-6.

66. Grimshaw MJ, Cooper L, Papazisis K, Coleman JA, Bohnenkamp HR, Chiapero-Stanke L, Taylor-Papadimitriou J, Burchell JM. Mammosphere culture of metastatic breast cancer cells enriches for tumorigenic breast cancer cells. Breast Cancer Res. 2008;10:R52.

67. Morata-Tarifa C, Jiménez G, García MA, Entrena JM, Griñán-Lisón C, Aguilera M, Picon-Ruiz M, Marchal JA. Low adherent cancer cell subpopulations are enriched in tumorigenic and metastatic epithelial-to-mesenchymal transition-induced cancer stem-like cells. Sci Rep. 2016;6:18772.

68. Reynolds DS, Tevis KM, Blessing WA, Colson YL, Zaman MH, Grinstaff MW. Breast cancer spheroids reveal a differential cancer stem cell response to chemotherapeutic treatment. Sci Rep. 2017;7:10382.

69. Liu J, Ma L, Xu J, Liu C, Zhang J, Liu J, Chen R, Zhou Y. Spheroid bodyforming cells in the human gastric cancer cell line MKN-45 possess cancer stem cell properties. Int J Oncol. 2013;42:453-9.

70. Misuno K, Liu X, Feng S, Hu S. Quantitative proteomic analysis of sphere-forming stem-like oral cancer cells. Stem Cell Res Therapy. 2013;4:156

71. Saleem S, Jamshed A, Faisal S, Hussain R, Tahseen M, Loya A, Sutton C. Patterns of cancer cell sphere formation in primary cultures of human oral tongue squamous cell carcinoma and neck nodes. Cancer Cell Int. 2014;14:542.

72. Chen Y-K, Huang AH-C, Lin L-M. Sphere-forming-like cells (squamospheres) with cancer stem-like cell traits from VX2 rabbit buccal squamous cell carcinoma. Int J Oral Sci. 2014;6:212.

73. Chen C, Wei Y, Hummel M, Hoffmann TK, Gross M, Kaufmann AM, Albers AE. Evidence for epithelial-mesenchymal transition in cancer stem cells of head and neck squamous cell carcinoma. PLoS ONE. 2011;6:e16466.

74. Vlashi E, Chen AM, Boyrie S, Yu G, Nguyen A, Brower PA, Hess CB, Pajonk F. Radiation-induced dedifferentiation of head and neck cancer cells into cancer stem cells depends on human papillomavirus status. Int J Radiat Oncol Biol Phys. 2016;94:1198-206.

75. Dittmar T, Nagler C, Schwitalla S, Reith G, Niggemann B, Zänker KS. Recurrence cancer stem cells-made by cell fusion? Med Hypotheses. 2009;73:542-7.

76. Wang J, Guo LP, Chen LZ, Zeng YX, Lu SH. Identification of cancer stem cell-like side population cells in human nasopharyngeal carcinoma cell line. Cancer Res. 2007;67:3716-24.

77. Huang CX, Zhu Y, Duan GL, Yao JF, Li ZY, Li D, Wang QQ. Screening for MiRNAs related to laryngeal squamous carcinoma stem cell radiation. Asian Pac J Cancer Prev. 2013;14:4533-7.

78. Choi SH, Cho KJ, Nam SY, Lee SW, Kang J, Kim SY. Clinical significance of beta1 integrin expression as a prediction marker for radiotherapy in early glottic carcinoma. Laryngoscope. 2006;116:1228-31.

79. Bertrand G, Maalouf M, Boivin A, Battiston-Montagne P, Beuve M, Levy A, Jalade P, Fournier C, Ardail D, Magne N, et al. Targeting head and neck cancer stem cells to overcome resistance to photon and carbon ion radiation. Stem Cell Rev Rep. 2014;10:114-26. 
80. Mishra L, Shetty K, Tang Y, Stuart A, Byers SW. The role of TGF- $\beta$ and Wnt signaling in gastrointestinal stem cells and cancer. Oncogene. 2005;24:5775.

81. Zhang L, Ye Y, Long $X$, Xiao P, Ren X, Yu J. BMP signaling and its paradoxical effects in tumorigenesis and dissemination. Oncotarget. 2016;7:78206.

82. Siddique HR, Saleem M. Role of BMI1, a stem cell factor, in cancer recurrence and chemoresistance: preclinical and clinical evidences. Stem Cells. 2012;30:372-8.

83. Hill R, Wu H. PTEN, stem cells, and cancer stem cells. J Biol Chem. 2009;284:11755-9.

84. O'Brien CA, Kreso A, Jamieson CH. Cancer stem cells and self-renewal. Clin Cancer Res. 2010;16:3113-20.

85. Giles RH, Es JH, Clevers H. Caught up in a Wht storm: Wnt signaling in cancer. Biochim Biophys Acta Rev Cancer. 2003;1653:1-24.

86. Liu S, Dontu G, Mantle ID, Patel S, Ahn N-S, Jackson KW, Suri P, Wicha MS. Hedgehog signaling and Bmi-1 regulate self-renewal of normal and malignant human mammary stem cells. Cancer Res. 2006;66:6063-71.

87. Leong KG, Karsan A. Recent insights into the role of notch signaling in tumorigenesis. Blood. 2006;107:2223-33.

88. Horikiri Y, Shimo T, Kurio N, Okui T, Matsumoto K, Iwamoto M, Sasaki A. Sonic hedgehog regulates osteoblast function by focal adhesion kinase signaling in the process of fracture healing. PLOS ONE. 2013;8:e76785.

89. Kalluri $R$, Weinberg RA. The basics of epithelial-mesenchymal transition. J Clin Investig. 2009;119:1420-8.

90. Cavallaro U, Christofori G. Cell adhesion and signalling by cadherins and Ig-CAMs in cancer. Nat Rev Cancer. 2004;4:118.

91. Zeisberg M, Neilson EG. Biomarkers for epithelial-mesenchymal transitions. J Clin Investig. 2009;119:1429-37.

92. Fan F, Samuel S, Evans KW, Lu J, Xia L, Zhou Y, Sceusi E, Tozzi F, Ye XC, Mani SA. Overexpression of Snail induces epithelial-mesenchymal transition and a cancer stem cell-like phenotype in human colorectal cancer cells. Cancer Med. 2012;1:5-16.

93. Dieter SM, Ball CR, Hoffmann CM, Nowrouzi A, Herbst F, Zavidij O, Abel U, Arens A, Weichert W, Brand K. Distinct types of tumor-initiating cells form human colon cancer tumors and metastases. Cell Stem Cell. 2011;9:357-65.

94. Liu Z-H, Dai X-M, Du B. Hes1: a key role in stemness, metastasis and multidrug resistance. Cancer Biol Therapy. 2015;16(3):353-9.

95. Chu P-Y, Hu F-W, Yu C-C, Tsai L-L, Yu C-H, Wu B-C, Chen Y-W, Huang P-I, Lo W-L. Epithelial-mesenchymal transition transcription factor ZEB1/ ZEB2 co-expression predicts poor prognosis and maintains tumor-initiating properties in head and neck cancer. Oral Oncol. 2013;49:34-41.

96. Kathawala RJ, Gupta P, Ashby CR Jr, Chen Z-S. The modulation of ABC transporter-mediated multidrug resistance in cancer: a review of the past decade. Drug Resist Updates. 2015;18:1-17.

97. Braunholz D, Saki M, Niehr F, Öztürk M, Puertolas BB, Konschak R, Budach $V$, Tinhofer I. Spheroid culture of head and neck cancer cells reveals an important role of EGFR signalling in anchorage independent survival. PLoS ONE. 2016;11:e0163149.

98. Shukla S, Ohnuma S, Ambudkar VS. Improving cancer chemotherapy with modulators of $A B C$ drug transporters. Curr Drug Targets. 2011:12:621-30.

99. Cui H, Zhang JA, Chen Chen, Liu JJ. ABC transporter inhibitors in reversing multidrug resistance to chemotherapy. Curr Drug Targets. 2015;16:1356-71.

100. Song J, Chang I, Chen Z, Kang M, Wang C-Y. Characterization of side populations in HNSCC: highly invasive, chemoresistant and abnormal Wnt signaling. PLOS ONE. 2010;5:e11456.

101. Golebiewska A, Brons NH, Bjerkvig R, Niclou SP. Critical appraisal of the side population assay in stem cell and cancer stem cell research. Cell Stem Cell. 2011;8:136-47.

102. Zhang $P$, Zhang $Y$, Mao L, Zhang Z, Chen W. Side population in oral squamous cell carcinoma possesses tumor stem cell phenotypes. Cancer Lett. 2009;277:227-34.

103. Yanamoto S, Kawasaki G, Yamada S-I, Yoshitomi I, Kawano T, Yonezawa H, Rokutanda S, Naruse T, Umeda M. Isolation and characterization of cancer stem-like side population cells in human oral cancer cells. Oral oncology. 2011;47:855-60.

104. Rinkenbaugh AL, Baldwin AS: The NF-kappaB pathway and cancer stem cells. Cells. 2016;5.
105. Garner JM, Fan M, Yang CH, Du Z, Sims M, Davidoff AM, Pfeffer LM. Constitutive activation of signal transducer and activator of transcription 3 (STAT3) and nuclear factor kappaB signaling in glioblastoma cancer stem cells regulates the Notch pathway. J Biol Chem. 2013;288:26167-76.

106. Liu R, Wang X, Chen GY, Dalerba P, Gurney A, Hoey T, Sherlock G, Lewicki J, Shedden K, Clarke MF. The prognostic role of a gene signature from tumorigenic breast-cancer cells. N Engl J Med. 2007:356:217-26.

107. Murohashi M, Hinohara K, Kuroda M, Isagawa T, Tsuji S, Kobayashi S, Umezawa K, Tojo A, Aburatani H, Gotoh N. Gene set enrichment analysis provides insight into novel signalling pathways in breast cancer stem cells. Br J Cancer. 2010;102:206-12.

108. Bano N, Yadav M, Mohania D, Das BC. The role of NF-kappaB and miRNA in oral cancer and cancer stem cells with or without HPV16 infection. PLoS One. 2018;13:e0205518.

109. Lee SH, Lee C-R, Rigas NK, Kim RH, Kang MK, Park N-H, Shin K-H. Human papillomavirus 16 (HPV16) enhances tumor growth and cancer stemness of HPV-negative oral/oropharyngeal squamous cell carcinoma cells via miR-181 regulation. Papillomavirus Res. 2015;1:116-25

110. Song SJ, Poliseno L, Song MS, Ala U, Webster K, Ng C, Beringer G, Brikbak NJ, Yuan X, Cantley LC. MicroRNA-antagonism regulates breast cancer stemness and metastasis via TET-family-dependent chromatin remodeling. Cell. 2013;154:311-24.

111. Liu C, Kelnar K, Liu B, Chen X, Calhoun-Davis T, Li H, Patrawala L, Yan H, Jeter $\mathrm{C}$, Honorio S. The microRNA miR-34a inhibits prostate cancer stem cells and metastasis by directly repressing CD44. Nat Med. 2011;17:211.

112. Mirzaei H, Yazdi F, Salehi R, Mirzaei HR. SiRNA and epigenetic aberrations in ovarian cancer. J Cancer Res Ther. 2016;12:498-508.

113. Khani P, Nasri F, Khani Chamani F, Saeidi F, Sadri Nahand J, Tabibkhooei A, Mirzaei H. Genetic and epigenetic contribution to astrocytic gliomas pathogenesis. J Neurochem. 2019;148:188-203.

114. Moridikia A, Mirzaei H. MicroRNAs: potential candidates for diagnosis and treatment of colorectal cancer. J Cell Physiol. 2018:233:901-13.

115. Saadatpour L, Fadaee E, Fadaei S, Nassiri Mansour R, Mohammadi M, Mousavi SM, Goodarzi M, Verdi J, Mirzaei H. Glioblastoma: exosome and microRNA as novel diagnosis biomarkers. Cancer Gene Ther. 2016;23:415-8.

116. Nahand JS, Taghizadeh-Boroujeni S, Karimzadeh M, Borran S, Pourhanifeh MH, Moghoofei M, Bokharaei-Salim F, Karampoor S, Jafari A, Asemi Z, et al. microRNAs: new prognostic, diagnostic, and therapeutic biomarkers in cervical cancer. J Cell Physiol. 2019;234:17064-99.

117. Naeli P, Yousefi F, Ghasemi Y, Savardashtaki A, Mirzaei H. The role of microRNAs in lung cancer: implications for diagnosis and therapy. Curr Mol Med. 2020;20:90-101.

118. Aghdam AM, Amiri A, Salarinia R, Masoudifar A, Ghasemi F, Mirzaei H. MicroRNAs as diagnostic, prognostic, and therapeutic biomarkers in prostate cancer. Crit Rev Eukaryot Gene Exp. 2019;29:127-39.

119. Kooistra SM, Helin K. Molecular mechanisms and potential functions of histone demethylases. Nat Rev Mol Cell Biol. 2012;13:297.

120. Ye L, Fan Z, Yu B, Chang J, Al Hezaimi K, Zhou X, Park N-H, Wang C-Y. Histone demethylases KDM4B and KDM6B promotes osteogenic differentiation of human MSCs. Cell Stem Cell. 2012;11:50-61.

121. Hsia DA, Tepper CG, Pochampalli MR, Hsia EY, Izumiya C, Huerta SB, Wright ME, Chen H-W, Kung H-J, Izumiya Y. KDM8, a H3K36me2 histone demethylase that acts in the cyclin $\mathrm{A} 1$ coding region to regulate cancer cell proliferation. Proc Natl Acad Sci. 2010;107:9671-6.

122. Agger K, Cloos PA, Rudkjær L, Williams K, Andersen G, Christensen J, Helin K. The H3K27me3 demethylase JMJD3 contributes to the activation of the INK4A-ARF locus in response to oncogene-and stressinduced senescence. Genes Dev. 2009;23:1171-6.

123. Ramadoss S, Chen X, Wang C-Y. Histone demethylase KDM6B promotes epithelial-mesenchymal transition. J Biol Chem. 2012;287:44508-17.

124. Li J, Yu B, Deng P, Cheng Y, Yu Y, Kevork K, Ramadoss S, Ding X, Li X, Wang C-Y. KDM3 epigenetically controls tumorigenic potentials of human colorectal cancer stem cells through Wnt/ $\beta$-catenin signalling. Nat Commun. 2017;8:15146.

125. Sherry-Lynes MM, Sengupta S, Kulkarni S, Cochran BH. Regulation of the JMJD3 (KDM6B) histone demethylase in glioblastoma stem cells by STAT3. PLOS ONE. 2017:12:e0174775. 
126. Yan Q, Zhang S-M, Meeth K, Micevic G, Bosenberg M. Histone demethylase KDM5B is critical for PI3K-AKT-mTOR signaling and stemness of melanoma. FASEB J. 2017:31:468.

127. Yamamoto $S$, Tateishi $K$, Kudo $Y$, Yamamoto $K$, Isagawa T, Nagae G, Nakatsuka T, Asaoka Y, ljichi H, Hirata Y. Histone demethylase KDM4C regulates sphere formation by mediating the cross talk between Wht and Notch pathways in colonic cancer cells. Carcinogenesis. 2013;34:2380-8

128. Metzger E, Stepputtis SS, Strietz J, Preca B-T, Urban S, Willmann D, Allen A, Zenk F, lovino N, Bronsert P. KDM4 inhibition targets breast cancer stem-like cells. Cancer Res. 2017;77:5900-12.

129. Harmeyer KM, Facompre ND, Herlyn M, Basu D. JARID1 histone demethylases: emerging targets in cancer. Trends Cancer. 2017;3:713-25.

130. Amente $S$, Lania L, Majello B. The histone LSD1 demethylase in stemness and cancer transcription programs. Bioch Biophys Acta Gene Regul Mech. 2013;1829:981-6.

131. Chang B, Chen Y, Zhao Y, Bruick RK. JMJD6 is a histone arginine demethylase. Science. 2007;318:444-7.

132. Webby CJ, Wolf A, Gromak N, Dreger M, Kramer H, Kessler B, Nielsen ML, Schmitz C, Butler DS, Yates JR. Jmjd6 catalyses lysyl-hydroxylation of U2AF65, a protein associated with RNA splicing. Science. 2009;325:90-3.

133. Lee YF, Miller LD, Chan XB, Black MA, Pang B, Ong CW, Salto-Tellez M, Liu ET, Desai KV. JMJD6 is a driver of cellular proliferation and motility and a marker of poor prognosis in breast cancer. Breast Cancer Res. 2012;14:3001.

134. Boeckel J-N, Guarani V, Koyanagi M, Roexe T, Lengeling A, Schermuly RT, Gellert P, Braun T, Zeiher A, Dimmeler S. Jumonji domain-containing protein $6(\mathrm{Jmjd} 6)$ is required for angiogenic sprouting and regulates splicing of VEGF-receptor 1. Proc Natl Acad Sci. 2011;108:3276-81.

135. Hao J, Zhang Y, Deng M, Ye R, Zhao S, Wang Y, Li J, Zhao Z. MicroRNA control of epithelial-mesenchymal transition in cancer stem cells. Int J Cancer. 2014;135:1019-27.

136. Schmitt AM, Chang HY. Long Noncoding RNAs in Cancer Pathways. Cancer Cell. 2016;29:452-63.

137. Vafadar A, Shabaninejad Z, Movahedpour A, Mohammadi S, Fathullahzadeh S, Mirzaei HR, Namdar A, Savardashtaki A, Mirzaei H. Long non-coding RNAs as epigenetic regulators in cancer. Curr Pharm Des. 2019:25:3563-77.

138. Shabaninejad Z, Vafadar A, Movahedpour A, Ghasemi Y, Namdar A, Fathizadeh H, Pourhanifeh MH, Savardashtaki A, Mirzaei H. Circular RNAs in cancer: new insights into functions and implications in ovarian cancer. J Ovarian Res. 2019:12:84

139. Saeedi Borujeni MJ, Esfandiary E, Baradaran A, Valiani A, Ghanadian M, Codoner-Franch P, Basirat R, Alonso-Iglesias E, Mirzaei H. Molecular aspects of pancreatic beta-cell dysfunction: Oxidative stress, microRNA, and long noncoding RNA. J Cell Physiol. 2019;234:8411-25.

140. Abbaszadeh-Goudarzi K, Radbakhsh S, Pourhanifeh MH, Khanbabaei H, Davoodvandi A, Fathizadeh H, Sahebkar A, Shahrzad MK, Mirzaei H. Circular RNA and diabetes: epigenetic regulator with diagnostic role. Curr Mol Med. 2020. https://doi.org/10.2174/15665240206662001291 42106.

141. Naeli P, Pourhanifeh MH, Karimzadeh MR, Shabaninejad Z, Movahedpour A, Tarrahimofrad H, Mirzaei HR, Bafrani HH, Savardashtaki A, Mirzaei H, Hamblin MR. Circular RNAs and gastrointestinal cancers: epigenetic regulators with a prognostic and therapeutic role. Crit Rev Oncol Hematol. 2020;145:102854.

142. Mirzaei H, Momeni F, Saadatpour L, Sahebkar A, Goodarzi M, Masoudifar A, Kouhpayeh S, Salehi H, Mirzaei HR, Jaafari MR. MicroRNA: relevance to stroke diagnosis, prognosis, and therapy. J Cell Physiol. 2018:233:856-65.

143. Gholamin S, Mirzaei H. GD2-targeted immunotherapy and potential value of circulating microRNAs in neuroblastoma. J Cell Physiol. 2018;233:866-79.

144. Jamali L, Tofigh R, Tutunchi S, Panahi G, Borhani F, Akhavan S, Nourmohammadi P, Ghaderian SMH, Rasouli M, Mirzaei H. Circulating microRNAs as diagnostic and therapeutic biomarkers in gastric and esophageal cancers. J Cell Physiol. 2018;233:8538-50.

145. Masoudi MS, Mehrabian E, Mirzaei H. MiR-21: a key player in glioblastoma pathogenesis. J Cell Biochem. 2018;1 19:1285-90.
146. Simonian M, Mosallayi M, Mirzaei H. Circulating miR-21 as novel biomarker in gastric cancer: diagnostic and prognostic biomarker. J Cancer Res Ther. 2018:14:475.

147. Fathullahzadeh S, Mirzaei H, Honardoost MA, Sahebkar A, Salehi M. Circulating microRNA-192 as a diagnostic biomarker in human chronic lymphocytic leukemia. Cancer Gene Ther. 2016;23:327-32.

148. Mashreghi M, Azarpara H, Bazaz MR, Jafari A, Masoudifar A, Mirzaei $\mathrm{H}$. Angiogenesis biomarkers and their targeting ligands as potential targets for tumor angiogenesis. J Cell Physiol. 2018;233:2949-65.

149. Taghavipour M, Sadoughi F, Mirzaei H, Yousefi B, Moazzami B, Chaichian S, Mansournia MA, Asemi Z. Apoptotic functions of microRNAs in pathogenesis, diagnosis, and treatment of endometriosis. Cell Biosci. 2020;10:12

150. Sadri Nahand J, Moghoofei M, Salmaninejad A, Bahmanpour Z, Karimzadeh M, Nasiri M, Mirzaei HR, Pourhanifeh MH, Bokharaei-Salim F, Mirzaei H. Pathogenic role of exosomes and microRNAs in HPVmediated inflammation and cervical cancer: a review. Int J Cancer. 2020;146:305-20.

151. Mohammadi M, Goodarzi M, Jaafari MR, Mirzaei HR, Mirzaei H. Circulating microRNA: a new candidate for diagnostic biomarker in neuroblastoma. Cancer Gene Ther. 2016;23:371-2.

152. Golabchi K, Soleimani-Jelodar R, Aghadoost N, Momeni F, Moridikia A, Nahand JS, Masoudifar A, Razmjoo H, Mirzaei H. MicroRNAs in retinoblastoma: potential diagnostic and therapeutic biomarkers. J Cell Physiol. 2018;233:3016-23.

153. Nahand JS, Karimzadeh MR, Nezamnia M, Fatemipour M, Khatami A, Jamshidi S, Moghoofei M, Taghizadieh M, Hajighadimi S, Shafiee A, et al. The role of miR-146a in viral infection. IUBMB Life. 2020;72:343-60.

154. Amiri A, Tehran MM, Asemi Z, Shafiee A, Hajighadimi S, Moradizarmehri S, Mirzaei HR, Mirzaei H. Role of resveratrol in modulating microRNAs in human diseases: From cancer to inflammatory disorder. Curr Med Chem. 2019. https://doi.org/10.2174/0929867326666191212102407.

155. Sadri Nahand J, Bokharaei-Salim F, Karimzadeh M, Moghoofei M, Karampoor S, Mirzaei HR, Tabibzadeh A, Jafari A, Ghaderi A, Asemi Z, et al. MicroRNAs and exosomes: key players in HIV pathogenesis. HIV Med. 2019;21(4):246-278.

156. Pakshir $\mathrm{K}$, Badali $\mathrm{H}$. Interactions between immune response to fungal infection and microRNAs: the pioneer tuners. Mycoses. 2020;63:4-20.

157. Shabaninejad Z, Yousefi F, Movahedpour A, Ghasemi Y, Dokanehiifard S, Rezaei S, Aryan R, Savardashtaki A, Mirzaei H. Electrochemical-based biosensors for microRNA detection: nanotechnology comes into view. Anal Biochem. 2019:581:113349.

158. Mirzaei H, Ferns GA, Avan A, Mobarhan MG. Cytokines and microRNA in coronary artery disease. Adv Clin Chem. 2017;82:47-70.

159. Jafari SH, Saadatpour Z, Salmaninejad A, Momeni F, Mokhtari M, Nahand JS, Rahmati M, Mirzaei H. Breast cancer diagnosis: Imaging techniques and biochemical markers. J Cell Physiol. 2018;233:5200-13.

160. Saeedi Borujeni MJ, Esfandiary E, Taheripak G, Codoner-Franch P, Alonso-Iglesias E, Mirzaei H. Molecular aspects of diabetes mellitus: resistin, microRNA, and exosome. J Cell Biochem. 2018;119:1257-72.

161. Mirzaei H. Stroke in women: risk factors and clinical biomarkers. J Cell Biochem. 2017;118:4191-202.

162. Tavakolizadeh J, Roshanaei K, Salmaninejad A, Yari R, Nahand JS, Sarkarizi HK, Mousavi SM, Salarinia R, Rahmati M, Mousavi SF, et al. MicroRNAs and exosomes in depression: potential diagnostic biomarkers. J Cell Biochem. 2018;119:3783-97.

163. Rashidi B, Hoseini Z, Sahebkar A, Mirzaei H. Anti-atherosclerotic effects of vitamins $\mathrm{d}$ and e in suppression of atherogenesis. J Cell Physiol. 2017;232:2968-76.

164. Kim T, Veronese A, Pichiorri F, Lee TJ, Jeon YJ, Volinia S, Pineau P, Marchio A, Palatini J, Suh SS, et al. p53 regulates epithelial-mesenchymal transition through microRNAs targeting ZEB1 and ZEB2. J Exp Med. 2011;208:875-83.

165. Ku TK, Nguyen DC, Karaman M, Gill P, Hacia JG, Crowe DL. Loss of p53 expression correlates with metastatic phenotype and transcriptional profile in a new mouse model of head and neck cancer. Mol Cancer Res. 2007;5:351-62.

166. Hollstein M, Rice K, Greenblatt MS, Soussi T, Fuchs R, Sorlie T, Hovig E, Smith-Sorensen B, Montesano R, Harris CC. Database of p53 gene somatic mutations in human tumors and cell lines. Nucleic Acids Res. 1994:22:3551-5. 
167. Yu CC, Tsai LL, Wang ML, Yu CH, Lo WL, Chang YC, Chiou GY, Chou MY, Chiou SH. miR145 targets the SOX9/ADAM17 axis to inhibit tumor-initiating cells and IL-6-mediated paracrine effects in head and neck cancer. Cancer Res. 2013;73:3425-40.

168. Shabaninejad Z, Pourhanifeh MH, Movahedpour A, Mottaghi R, Nickdasti A, Mortezapour E, Shafiee A, Hajighadimi S, Moradizarmehri S, Sadeghian M, et al. Therapeutic potentials of curcumin in the treatment of glioblstoma. Eur J Med Chem. 2020;188:112040.

169. Ahmed S, Khan H, Mirzaei H. Mechanics insights of curcumin in myocardial ischemia: where are we standing? Eur J Med Chem. 2019;183:111658.

170. Ghasemi F, Shafiee M, Banikazemi Z, Pourhanifeh MH, Khanbabaei H, Shamshirian A, Amiri Moghadam S, ArefNezhad R, Sahebkar A, Avan A, Mirzaei H. Curcumin inhibits NF-kB and Wnt/beta-catenin pathways in cervical cancer cells. Pathol Res Pract. 2019;215:152556.

171. Shafabakhsh R, Pourhanifeh MH, Mirzaei HR, Sahebkar A, Asemi Z, Mirzaei $H$. Targeting regulatory $T$ cells by curcumin: a potential for cancer immunotherapy. Pharmacol Res. 2019;147:104353.

172. Banikazemi Z, Haji HA, Mohammadi M, Taheripak G, Iranifar E, Poursadeghiyan M, Moridikia A, Rashidi B, Taghizadeh M, Mirzaei H. Diet and cancer prevention: dietary compounds, dietary MicroRNAs, and dietary exosomes. J Cell Biochem. 2018;119:185-96.

173. Mirzaei H, Masoudifar A, Sahebkar A, Zare N, Sadri Nahand J, Rashidi B, Mehrabian E, Mohammadi M, Mirzaei HR, Jaafari MR. MicroRNA: a novel target of curcumin in cancer therapy. J Cell Physiol. 2018;233:3004-15.

174. Mirzaei H, Khoi MJ, Azizi M, Goodarzi M. Can curcumin and its analogs be a new treatment option in cancer therapy? Cancer Gene Ther. 2016;23:410.

175. Mirzaei H, Naseri G, Rezaee R, Mohammadi M, Banikazemi Z, Mirzaei HR, Salehi H, Peyvandi M, Pawelek JM, Sahebkar A. Curcumin: a new candidate for melanoma therapy? Int J Cancer. 2016:139:1683-95.

176. Sun J, Lu F, He H, Shen J, Messina J, Mathew R, Wang D, Sarnaik AA, Chang W-C, Kim M. STIM1-and Orai1-mediated Ca ${ }^{2+}$ oscillation orchestrates invadopodium formation and melanoma invasion. J Cell Biol. 2014:207:535-48.

177. Zhu H, Zhang H, Jin F, Fang M, Huang M, Yang CS, Chen T, Fu L, Pan Z. Elevated Orai1 expression mediates tumor-promoting intracellular $\mathrm{Ca}^{2+}$ oscillations in human esophageal squamous cell carcinoma. Oncotarget. 2014;5:3455.

178. Zhao W, Wang L, Han H, Jin K, Lin N, Guo T, Chen Y, Cheng H, Lu F, Fang W. 1B50-1, a mAb raised against recurrent tumor cells, targets liver tumor-initiating cells by binding to the calcium channel a2 $\delta 1$ subunit. Cancer Cell. 2013;23:541-56

179. Prevarskaya N, Skryma R, Shuba Y. Calcium in tumour metastasis: new roles for known actors. Nat Rev Cancer. 2011;11:609.

180. Roderick HL, Cook SJ. $\mathrm{Ca}^{2+}$ signalling checkpoints in cancer: remodelling $\mathrm{Ca}^{2+}$ for cancer cell proliferation and survival. Nat Rev Cancer. 2008;8:361.

181. Monteith GR, McAndrew D, Faddy HM, Roberts-Thomson SJ. Calcium and cancer: targeting $\mathrm{Ca}^{2+}$ transport. Nat Rev Cancer. 2007;7:519.

182. Berridge MJ, Bootman MD, Roderick HL. Calcium: calcium signalling: dynamics, homeostasis and remodelling. Nat Rev Mol Cell Biol. 2003:4:517.

183. Srikanth S, Gwack Y. Molecular regulation of the pore component of CRAC channels, Orai1. In: Current topics in membranes. 71. Amsterdam: Elsevier; 2013. p. 181-207.

184. Gwack Y, Srikanth S, Feske S, Cruz-Guilloty F, Oh-hora M, Neems DS, Hogan PG, Rao A. Biochemical and functional characterization of Orai proteins. J Biol Chem. 2007;282:16232-43.

185. Prakriya M, Feske S, Gwack Y, Srikanth S, Rao A, Hogan PG. Orai1 is an essential pore subunit of the CRAC channel. Nature. 2006;443:230

186. Feske S, Gwack Y, Prakriya M, Srikanth S, Puppel S-H, Tanasa B, Hogan PG, Lewis RS, Daly M, Rao A. A mutation in Orai1 causes immune deficiency by abrogating CRAC channel function. Nature. 2006:441:179.

187. Parekh AB, Putney JW Jr. Store-operated calcium channels. Physiol Rev. 2005:85:757-810.

188. Parekh AB. Functional consequences of activating store-operated CRAC channels. Cell Calcium. 2007;42:111-21.

189. Srikanth S, Gwack Y. Orai1-NFAT signalling pathway triggered by T cell receptor stimulation. Mol Cells. 2013;35:182-94.
190. Zhan Z-Y, Zhong L-X, Feng M, Wang J-F, Liu D-B, Xiong J-P. Overexpression of Orai1 mediates cell proliferation and associates with poor prognosis in human non-small cell lung carcinoma. Int J Clin Exp Pathol. 2015;8:5080

191. Deng W, Wang J, Zhang J, Cai J, Bai Z, Zhang Z. Orai1, a direct target of microRNA-519, promotes progression of colorectal cancer via Akt/ GSK3ß signaling pathway. Dig Dis Sci. 2016;61:1553-60.

192. Xia J, Wang H, Huang H, Sun L, Dong S, Huang N, Shi M, Bin J, Liao Y, Liao W. Elevated Orai1 and STIM1 expressions upregulate MACC1 expression to promote tumor cell proliferation, metabolism, migration, and invasion in human gastric cancer. Cancer Lett. 2016;381:31-40.

193. Wang L, Hao J, Zhang Y, Yang Z, Cao Y, Lu W, Shu Y, Jiang L, Hu Y, Lv W. Orai1 mediates tumor-promoting store-operated $\mathrm{Ca}^{2+}$ entry in human gastrointestinal stromal tumors via c-KIT and the extracellular signalregulated kinase pathway. Tumor Biol. 2017;39:1010428317691426.

194. Kim J-H, Lkhagvadorj S, Lee M-R, Hwang K-H, Chung HC, Jung JH, Cha S-K, Eom M. Orai1 and STIM1 are critical for cell migration and proliferation of clear cell renal cell carcinoma. Biochem Biophys Res Commun. 2014;448:76-82.

195. Liu H, Hughes JD, Rollins S, Chen B, Perkins E. Calcium entry via ORAl1 regulates glioblastoma cell proliferation and apoptosis. Exp Mol Pathol. 2011;91:753-60

196. Yang S, Zhang JJ, Huang X-Y. Orai1 and STIM1 are critical for breast tumor cell migration and metastasis. Cancer Cell. 2009;15:124-34.

197. Flourakis M, Lehen'kyi V, Beck B, Raphael M, Vandenberghe M, Abeele FV, Roudbaraki M, Lepage G, Mauroy B, Romanin C. Orai1 contributes to the establishment of an apoptosis-resistant phenotype in prostate cancer cells. Cell Death Dis. 2010;1:e75.

198. Maul-Pavicic A, Chiang SC, Rensing-Ehl A, Jessen B, Fauriat C, Wood SM, Sjöqvist S, Hufnagel M, Schulze I, Bass T. ORAl1-mediated calcium influx is required for human cytotoxic lymphocyte degranulation and target cell lysis. Proc Natl Acad Sci. 2011;108:3324-9.

199. Gwack Y, Feske S, Srikanth S, Hogan PG, Rao A. Signalling to transcription: store-operated $\mathrm{Ca}^{2+}$ entry and NFAT activation in lymphocytes. Cell Calcium. 2007:42:145-56.

200. Xiao Z-J, Liu J, Wang S-Q, Zhu Y, Gao X-Y, Tin VP-C, Qin J, Wang J-W, Mong MP. NFATC2 enhances tumor-initiating phenotypes through the NFATC2/SOX2/ALDH axis in lung adenocarcinoma. Elife. 2017;6:e26733.

201. Hessmann E, Zhang J-S, Chen N-M, Hasselluhn M, Liou G-Y, Storz P, Ellenrieder V, Billadeau DD, Koenig A. NFATc4 regulates Sox9 gene expression in acinar cell plasticity and pancreatic cancer initiation. Stem Cells Int 2016:2016:5272498.

202. Perotti V, Baldassari P, Molla A, Vegetti C, Bersani I, Maurichi A, Santinami $\mathrm{M}$, Anichini A, Mortarini R. NFATC2 is an intrinsic regulator of melanoma dedifferentiation. Oncogene. 2016;35:2862.

203. Gerlach K, Daniel C, Lehr HA, Nikolaev A, Gerlach T, Atreya R, Rose-John S, Neurath MF, Weigmann B. Transcription factor NFATc2 controls the emergence of colon cancer associated with IL-6-dependent colitis. Cancer Res. 2012;72:4340-50.

204. Yoshida R, Nagata M, Nakayama H, Niimori-Kita K, Hassan W, Tanaka T, Shinohara M, Ito T. The pathological significance of Notch1 in oral squamous cell carcinoma. Lab Invest. 2013;93:1068.

205. Kageyama R, Ohtsuka T, Tomita K. The bHLH gene Hes1 regulates differentiation of multiple cell types. Mol Cells. 2000;10:1-7.

206. Kang MK. Polycomb group proteins: new targets of anti-cancer therapy. Cell Cycle. 2010;9:2704-12.

207. Kim RH, Kang MK, Shin K-H, Oo ZM, Han T, Baluda MA, Park N-H. Bmi-1 cooperates with human papillomavirus type 16 E6 to immortalize normal human oral keratinocytes. Exp Cell Res. 2007;313:462-72.

208. Wang Q, Li Z, Wu Y, Huang R, Zhu Y, Zhang W, Wang Y, Cheng J. Pharmacological inhibition of Bmi1 by PTC-209 impaired tumor growth in head neck squamous cell carcinoma. Cancer Cell Int. 2017;17:107.

209. Chen D, Wu M, Li Y, Chang I, Yuan Q, Ekimyan-Salvo M, Deng P, Yu B, Yu Y, Dong J. Targeting BMI1 + cancer stem cells overcomes chemoresistance and inhibits metastases in squamous cell carcinoma. Cell Stem Cell. 2017;20(621-634):e626.

210. Salarinia R, Sahebkar A, Peyvandi M, Mirzaei HR, Jaafari MR, Riahi MM, Ebrahimnejad H, Nahand JS, Hadjati J, Asrami MO, et al. Epi-drugs and Epi-miRs: moving beyond current cancer therapies. Curr Cancer Drug Targets. 2016;16:773-88. 
211. Saadatpour Z, Bjorklund G, Chirumbolo S, Alimohammadi M, Ehsani H, Ebrahiminejad H, Pourghadamyari H, Baghaei B, Mirzaei HR, Sahebkar A, et al. Molecular imaging and cancer gene therapy. Cancer Gene Ther. 2016. https://doi.org/10.1038/cgt.2016.62.

212. Saadatpour Z, Rezaei A, Ebrahimnejad H, Baghaei B, Bjorklund G, Chartrand M, Sahebkar A, Morovati H, Mirzaei HR, Mirzaei H. Imaging techniques: new avenues in cancer gene and cell therapy. Cancer Gene Ther. 2017;24:1-5.

213. Mirzaei H, Shakeri A, Rashidi B, Jalili A, Banikazemi Z, Sahebkar A. Phytosomal curcumin: a review of pharmacokinetic, experimental and clinical studies. Biomed Pharmacother. 2017;85:102-12.

214. Mirzaei HR, Mirzaei H, Lee SY, Hadjati J, Till BG. Prospects for chimeric antigen receptor (CAR) gammadelta T cells: a potential game changer for adoptive $T$ cell cancer immunotherapy. Cancer Lett. 2016;380:413-23.

215. Mirzaei HR, Pourghadamyari H, Rahmati M, Mohammadi A, Nahand JS, Rezaei A, Mirzaei H, Hadjati J. Gene-knocked out chimeric antigen receptor (CAR) T cells: tuning up for the next generation cancer immunotherapy. Cancer Lett. 2018;423:95-104.

216. Vakili-Ghartavol R, Mombeiny R, Salmaninejad A, Sorkhabadi SMR, Faridi-Majidi R, Jaafari MR, Mirzaei H. Tumor-associated macrophages and epithelial-mesenchymal transition in cancer: nanotechnology comes into view. J Cell Physiol. 2018;233:9223-36.

217. Khan H, Mirzaei HR, Amiri A, Kupeli Akkol E, Ashhad Halimi SM, Mirzaei H. Glyco-nanoparticles: new drug delivery systems in cancer therapy. Semin Cancer Biol. 2019. https://doi.org/10.1016/j.semca ncer.2019.12.004.

218. Sadeghi S, Davoodvandi A, Pourhanifeh MH, Sharifi N, ArefNezhad R, Sahebnasagh R, Moghadam SA, Sahebkar A, Mirzaei H. Anti-cancer effects of cinnamon: insights into its apoptosis effects. Eur J Med Chem. 2019:178:131-40.

219. Davoodvandi A, Sahebnasagh R, Mardanshah O, Asemi Z, Nejati M, Shahrzad MK, Mirzaei HR, Mirzaei H. Medicinal plants as natural polarizers of macrophages: phytochemicals and pharmacological effects. Curr Pharm Des. 2019;25:3225-38.

220. Birkeland AC, Owen JH, Prince ME. Targeting head and neck cancer stem cells: current advances and future challenges. J Dent Res. 2015:94:1516-23.

221. Damek-Poprawa M, Volgina A, Korostoff J, Sollecito TP, Brose MS, O'Malley BW Jr, Akintoye SO, DiRienzo JM. Targeted inhibition of CD133+ cells in oral cancer cell lines. J Dent Res. 2011;90:638-45.

222. Waldron NN, Kaufman DS, Oh S, Inde Z, Hexum MK, Ohlfest JR, Vallera DA. Targeting tumor-initiating cancer cells with dCD133KDEL shows impressive tumor reductions in a xenotransplant model of human head and neck cancer. Mol Cancer Ther. 2011;10:1829-38.

223. Murillo-Sauca O, Chung MK, Shin JH, Karamboulas C, Kwok S, Jung YH, Oakley R, Tysome JR, Farnebo LO, Kaplan MJ, et al. CD271 is a functional and targetable marker of tumor-initiating cells in head and neck squamous cell carcinoma. Oncotarget. 2014;5:6854-66.

224. Kuo SZ, Blair KJ, Rahimy E, Kiang A, Abhold E, Fan JB, Wang-Rodriguez J, Altuna X, Ongkeko WM. Salinomycin induces cell death and differentiation in head and neck squamous cell carcinoma stem cells despite activation of epithelial-mesenchymal transition and Akt. BMC Cancer. 2012;12:556.

225. Chiu CC, Lee LY, Li YC, Chen YJ, Lu YC, Li YL, Wang HM, Chang JT, Cheng AJ. Grp78 as a therapeutic target for refractory head-neck cancer with CD24(-)CD44(+) stemness phenotype. Cancer Gene Ther. 2013;20:606-15.

226. Huang CE, Yu CC, Hu FW, Chou MY, Tsai LL. Enhanced chemosensitivity by targeting Nanog in head and neck squamous cell carcinomas. Int J Mol Sci. 2014;15:14935-48.
227. Chang CW, Chen YS, Chou SH, Han CL, Chen YJ, Yang CC, Huang CY, Lo JF. Distinct subpopulations of head and neck cancer cells with different levels of intracellular reactive oxygen species exhibit diverse stemness, proliferation, and chemosensitivity. Cancer Res. 2014;74:6291-305.

228. Ma L, Zhang G, Miao XB, Deng XB, Wu Y, Liu Y, Jin ZR, Li XQ, Liu QZ, Sun DX, et al. Cancer stem-like cell properties are regulated by EGFR/ AKT/beta-catenin signaling and preferentially inhibited by gefitinib in nasopharyngeal carcinoma. FEBS J. 2013;280:2027-41.

229. Wan G, Zhou L, Xie M, Chen H, Tian J. Characterization of side population cells from laryngeal cancer cell lines. Head Neck. 2010;32:1302-9.

230. Katayama R, Koike S, Sato S, Sugimoto Y, Tsuruo T, Fujita N. Dofequidar fumarate sensitizes cancer stem-like side population cells to chemotherapeutic drugs by inhibiting ABCG2/BCRP-mediated drug export. Cancer Sci. 2009;100:2060-8.

231. Gan GN, Eagles J, Keysar SB, Wang G, Glogowska MJ, Altunbas C, Anderson RT, Le PN, Morton JJ, Frederick B, et al. Hedgehog signaling drives radioresistance and stroma-driven tumor repopulation in head and neck squamous cancers. Cancer Res. 2014;74:7024-36.

232. Pai S, Bamodu OA. CD47-SIRPalpha signaling induces epithelial-mesenchymal transition and cancer stemness and links to a poor prognosis in patients with oral squamous cell carcinoma. 2019;8.

233. Keysar SB, Gomes N. Inhibiting translation elongation with SVC112 suppresses cancer stem cells and inhibits growth in head and neck squamous carcinoma. Cancer Res. 2020;80(5):1183-98.

234. Han Z, Li Q, Wang Y, Wang L, Li X, Ge N, Wang Y, Guo C. Niclosamide induces cell cycle arrest in $\mathrm{G} 1$ phase in head and neck squamous cell carcinoma through Let-7d/CDC34 axis. Front Pharmacol. 2018;9:1544.

235. Kerk SA, Finkel KA, Pearson AT, Warner KA, Zhang Z, Nor F, Wagner VP, Vargas PA, Wicha MS, Hurt EM, et al. 5T4-targeted therapy ablates cancer stem cells and prevents recurrence of head and neck squamous cell carcinoma. Clin Cancer Res. 2017;23:2516-27.

236. Sun S, Liu S, Duan SZ, Zhang L, Zhou H, Hu Y, Zhou X, Shi C, Zhou R, Zhang $Z$. Targeting the c-Met/FZD8 signaling axis eliminates patientderived cancer stem-like cells in head and neck squamous carcinomas. Cancer Res. 2014;74:7546-59.

237. Odenthal J, Rijpkema M, Bos D, Wagena E, Croes H, Grenman R, Boerman O, Takes R, Friedl P. Targeting CD44v6 for fluorescence-guided surgery in head and neck squamous cell carcinoma. Sci Rep. 2018;8:10467.

238. Colnot DR, Quak JJ, Roos JC, van Lingen A, Wilhelm AJ, van Kamp GJ, Huijgens PC, Snow GB, van Dongen GA. Phase I therapy study of 186Relabeled chimeric monoclonal antibody U36 in patients with squamous cell carcinoma of the head and neck. J Nucl Med. 2000;41:1999-2010.

239. Kim J, Shin JH, Chen CH, Cruz L, Farnebo L, Yang J, Borges P, Kang G, Mochly-Rosen D, Sunwoo JB. Targeting aldehyde dehydrogenase activity in head and neck squamous cell carcinoma with a novel small molecule inhibitor. Oncotarget. 2017;8:52345-56.

240. Liu J, Pan S, Hsieh MH, Ng N, Sun F, Wang T, Kasibhatla S, Schuller AG, Li $A G$, Cheng $D$, et al. Targeting Wnt-driven cancer through the inhibition of Porcupine by LGK974. Proc Natl Acad Sci USA. 2013;110:20224-9.

241. McDermott SC, Rodriguez-Ramirez C, McDermott SP, Wicha MS, Nor JE. FGFR signaling regulates resistance of head and neck cancer stem cells to cisplatin. Oncotarget. 2018;9:25148-65.

\section{Publisher's Note}

Springer Nature remains neutral with regard to jurisdictional claims in published maps and institutional affiliations. 